\title{
Overview of the Bosphorus Depositional Fan from Data Sets Recovered on the Black Sea Shelf off the Strait of Istanbul
}

\author{
Gilles Lericolais ${ }^{1 *}$, Oya Algan ${ }^{2}$, Caterina Morigi ${ }^{3}$, Seda 0 kay $^{4}$, Elmas Kirci-Elmas ${ }^{2}$ and Günay Çifçi ${ }^{4}$ \\ ${ }^{1}$ IFREMER, ZI Pointe du Diable, France \\ ${ }^{2}$ Institute of Marine Sciences and Management, Istanbul University, Turkey \\ ${ }^{3}$ Department of Earth Sciences, University of Pisa, Italy \\ ${ }^{4}$ Institute of Marine Sciences and Technology, Dokuz Eylül University, Turkey
}

Submission: January 25, 2019; Published: February 13, 2019

*Corresponding author: Gilles Lericolais, IFREMER, ZI Pointe du Diable, CS 10070, F-29280 PLOUZANÉ, France

\begin{abstract}
Since the preliminary mapping of the northern Bosphorus outlet of the Black Sea continental shelf by the 90's NATO project, an important data set bringing morphological, seismic and sedimentological information is now available to describe there a shallow fan system consisting of a main channel and short distributary branches, levees, and sediment waves, correlative to a southern source flowing to the north. This paper brings complementary quantitative data from landscape at the eastern and western shelf area of the shallow fan system. It confirms that the Bosphorus outlet fan preserved on the shelf surface provides an important record of surface water flow. To deduce the history of the Marmara/ Black Sea last connexion, it is fundamental to understand how surface water flow could have generated the observed morphology. To date, morphological studies propose only very short time estimates for the longevity of the necessary hydrological events responsible for this deposit. Here we propose a compilation of multibeam bathymetry data from previous studies completed with multibeam bathymetric data collected from new areas not previously studied, together with high resolution seismic data (Chirp) and gravity cores from the confluence of the Bosphorus and Black Sea. This compilation shows that this shallow fan delta is in all points comparable to a depositional fan with a branching pattern of channels mimicking a mostly exposed fan-shaped body prograding from the foot of a significant break in slope and extending from the outlet of the strait to the shelf edge. Although we do not entirely resolve the ongoing controversies, we provide extra data to obtain a wider view to this key area. Using analogue cases and flume studies, it is acceptable to propose that the distinct morphology of this form of fan delta could have been the result of a single event of basin-filling on a timescale of decades after a relatively strong Mediterranean-originated northerly flow into the partly sub aerially exposed shelf area earlier than $8.5 \mathrm{ky}$ BP reshaped by present day saline undercurrent processes.
\end{abstract}

Keywords: Bosphorus; Black Sea; seismic; sediment cores; multibeam bathymetry; shallow fan

\section{Introduction}

Although the structure of Bosphorus outlet submarine channels had been visually evidenced by analogue echo-sounding [1], the first multibeam images were obtained in 1999 by the NATO RV Alliance and the Turkish Navy survey ship Cubuklu, in the framework of a NATO SACLANT Undersea Research project [2]. These shelf features were initially described as grooves by Özsoy et al. [3]. In 2002, a survey carried out on board the Ifremer RV Le Suroit for BlaSON project [4] increased the multibeam mapping of this underwater channel fan-delta and canyons system. Since then, several other surveys were performed to complete this Black Sea anastomosed channel network mapping [5,6], also described as a subaqueous shelf fan [7] or a channelled shelf fan [8]. The mapped set of shelf-cut channels reaches the heads of recent submarine canyons which was recognized in 2002 (Figure 1) [4,9].

The Bosphorus (or Istanbul Strait) provides a sole outlet for the semi-enclosed Black Sea basin, connecting it to the Marmara Sea. It is almost $30 \mathrm{~km}$ long and $3.4 \mathrm{~km}$ wide at the northern outlet and $2.8 \mathrm{~km}$ at the southern inlet. In between, the Bosphorus strait displays a minimum width of $700 \mathrm{~m}[10,11]$. Its average depth is $65 \mathrm{~m}$ varying from approximately $15 \mathrm{~m}$ (depth of the channel rims) to $110 \mathrm{~m}$, its deepest part located in midstream of the channel. The inner channel begins off the southern sill $(27 \mathrm{~m}$ deep) and continues to the Black Sea outlet where it reaches $105 \mathrm{~m}$ (Figure 2). 


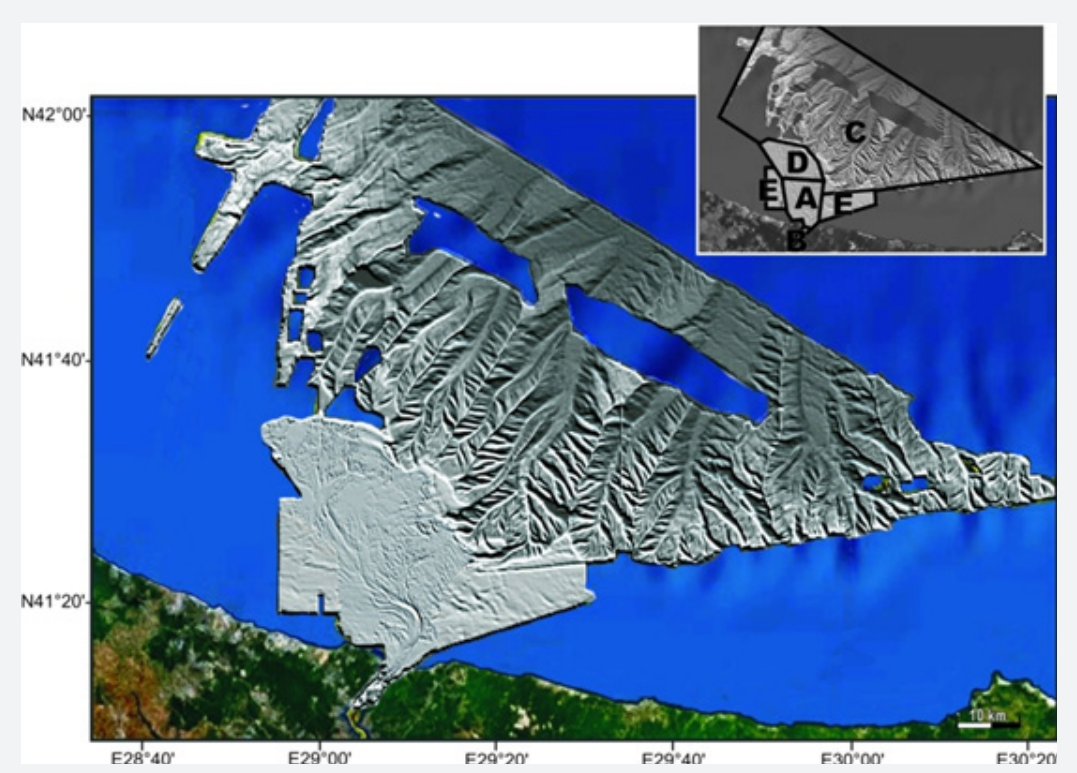

Figure 1: Multibeam bathymetric map of the South-Western Black Sea presenting the studied shelf fan. Synthesis was realized with data issued from:

A: Data collected during NRV Alliance and TCG Çubuklu cruises SACLANTCEN-SR269; Di lorio and Yüce [2].

B: Data collected by the Turkish Navy, Department of Navigation, Hydrography and Oceanography (TN-DNHO); Gökaşan et al. [10].

C: Data collected by R/V Le Suroit; Lericolais [4] and Okay et al. [7].

D: Data collected during the R/V Koca Piri Reis cruises MAR98 and MAR00; Flood et al. [5] and Hiscott et al. [6].

E: Data collected during the R/V Koca Piri Reis cruise PIA07; Algan et al. [76] and this study.

Two oppositely flowing currents

a) The upper layer with a salinity ranging from 18 to 20psu coming from the Black Sea and

b) The lower layer which salinity is ranging between 36 and 38psu coming from the Marmara Sea, characterize the physical oceanography of this conduit. Flow exchange is affected mainly by the hydraulic conditions generated by the geometry of the strait. One specific water mass through the strait is the cold intermediate water (CIW) observed in the Black Sea during the summer months $[12,13]$. The warm and more saline lower layer, called Mediterranean Sea Water (MSW), flows into the Black Sea [3,12,14]. For Özsoy et al. [3], the shelf edge structure of the delta and the channel morphology, i.e. curved and overflow channels, evoke river morphology, which corresponds today to the deep salt water flowing out of the Bosphorus channel into the Black Sea. For these authors, it was not clear whether these features were related to an ancient fresh-water stream.

The main sill corresponds to the shallowest part of the Bosphorus strait and is present at its southern entrance as a sedimentary deposit forming an elongated sill reaching a depth of only $27 \mathrm{~m}$ [10] (Figure 2). This sill had the ultimate control of the Marmara Black Sea connection. The Istanbul Strait multibeam bathymetric data (Figure 2) indicate that the morphology of the Strait is deepening northwards and its seafloor morphology is mainly characterized by erosion [10].

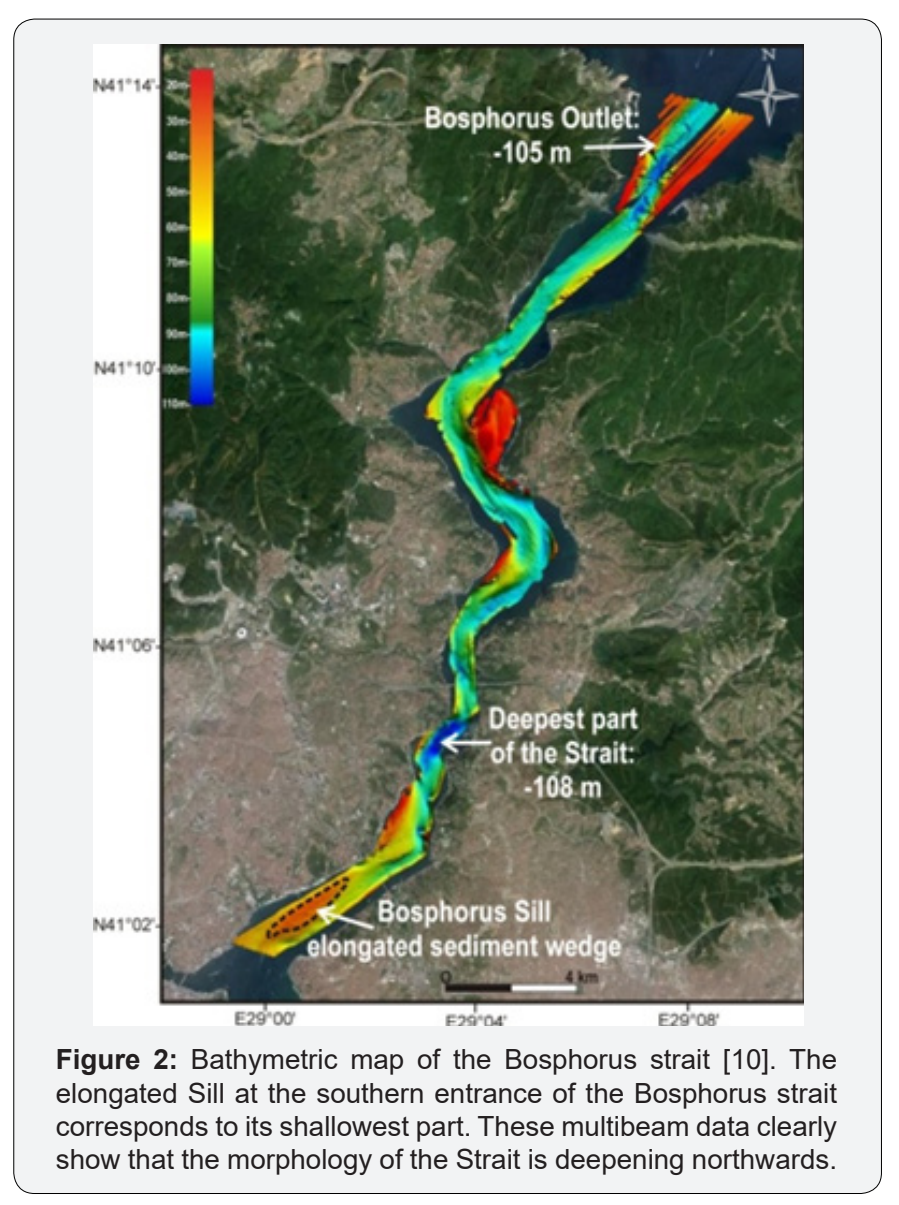


The Black Sea has been subjected to various depositional and erosional events due to the changing global sea level, during glacial and interglacial stages of Pleistocene. These sea level changes of the Black Sea are complicated and do not fully track the global sea level, due to its regional climatic conditions, confined geographical conditions and limited connection to the world ocean $[15,16]$. Its brackish-fresh conditions have changed to marine condition, since Holocene with the northward flowingundercurrent of Mediterranean waters from the Bosphorus [1722]. The last re-entrance of the Mediterranean waters into the Black Sea has been controversial and a matter of debate in terms of its mode and timing in the published studies carried out on the North-western and South-western shelf of the Black Sea, and in the Marmara Sea, from 1997 to 2011 [23-34]. Since 2011, the date of the last reconnection seems to have been widely agreed and would have occurred with the Initial Marine Inflow (IMI) dated around 8.9 - 8.5ky BP [16, 35-37] or 9.3-9ky BP $[38,39]$. The common results of some of these studies indicated a shelf-wide erosional surface with prograding wedge system (lowstand) of lacustrine shelf deposits at the shelf edge. This unconformity is overlain by various bedforms and sedimentary deposition and local erosional unconformities. The sedimentary deposits and bedforms on the shelf area were interpreted as formed in a shallow water-coastal environment [23,28-30,40].

The confluence of the Bosphorus and Black Sea at the inner shelf area is the critical site for understanding the processes that occurred in the recent past. Flood et al. [5] published a detailed morphological map of the channel network from the Bosphorus outlet to the shelf edge and discussed the sedimentological process in its evolution. Hiscott et al. [6] have documented the interaction of the overspill at the outlet with sea bed topography. And recently, Ryan et al. [8] considered that the synchronicity between the arrival of Mediterranean fauna and the onset of the Black Sea outlet fan construction suggests an origin linked to the connection of the Black Sea's lake with the global ocean.

In this study, we propose a compilation of multibeam bathymetry data from afore mentioned studies completed with multibeam bathymetric data collected from the surrounding areas, together with high resolution seismic data (Chirp) and gravity cores from the confluence of the Bosphorus and Black Sea. These data were collected in 2007 and 2008 by $R V K$. Piri Reis of Dokuz Eylül University, in the frame of a research project supported by TÜBITTAK, under the Programme of PIABOSPHORUS. The present detailed morphological and seismic data obtained at this particular confluence (Figure 1), will be compared to analogue features as alluvial fan or eroding rill network from the berm to the beach to supplement the previous published studies on the Bosphorus outlet shelf fan. These features are normally fleeting concentrated flow paths functioning not only as a source of sediment but also as sediment distribution systems creating slope erosion. They are interpreted as being formed by a stream competence loss flowing onto a flood plain or to a high-gradient stream reaching a body of water [41]. Such features form when the flow reaches its basal level and, as the power of the stream slows down, sediments are deposited at the foot of the slope when rapid water flows penetrate a shallow area. The dynamics then slow down and the sediments settle in the bed of the streambed creating patterns similar to the beach patterns visible on the beach when tide recedes (Figure 3).

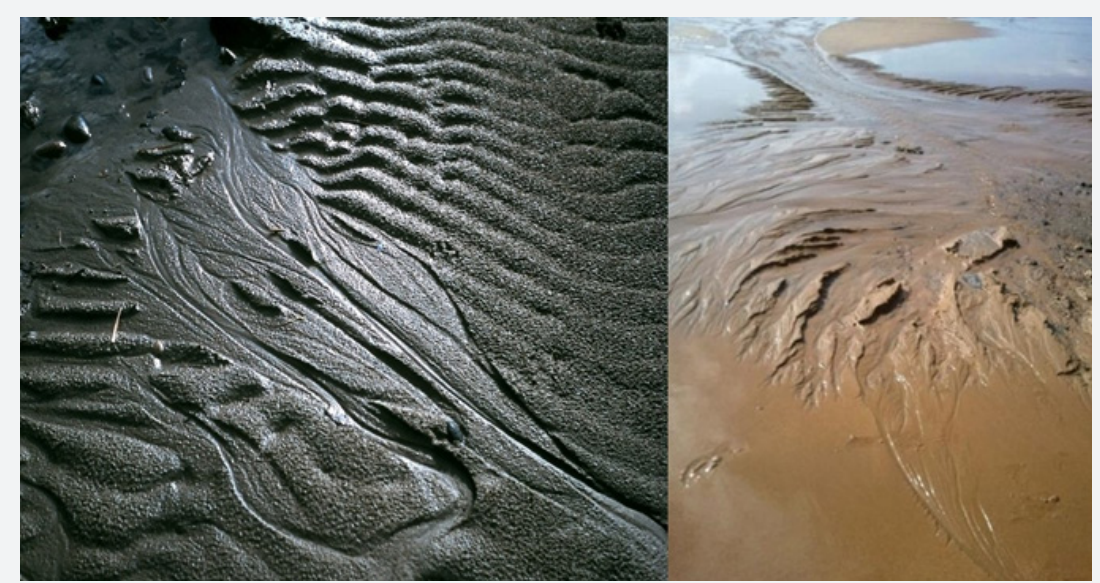

Figure 3: The receding waters of low tide or of flood stream on the beach leave behind similar patterns as the one recognized at the Bosphorus outlet, but at a reduced scale.

\section{Study Area}

\section{The bosphorus channel}

The Bosphorus (Istanbul Strait) is a zigzagging channel formed by conjugated pairs of oblique faults inside a meandering strait [42]. The geological evolution of the Bosphorus is formed by combine effects of tectonics of the region and a pre-existing fluvial system, and has an opening history that starts during the Pliocene with a series of tectonic movements of the North Anatolian Fault (NAF) extending to the Marmara Sea. Meandering physiography of the strait was shown to be resulted from the trends of the major faults along the both sides of the Bosphorus by various investigators $[11,42,43]$. The blocks bounded by conjugated pairs of oblique faults started to move away from 
each other, initially forming a channel, the Bosphorus began to shape as a zigzagging waterway, when the North Anatolian Fault extended into the Marmara region during the PliocenePleistocene period [42]. The basement in the Bosphorus channel is constituted by a sediment infill locally reaching a thickness of more than $130 \mathrm{~m}$ in the southern part overlying a Paleozoic and Upper-Cretaceous substratum. Previous drilling borehole data in the Central part of the Bosphorus indicate the intermittent deposition over the basement rock during the last 26ky BP with the appearance of first euryhaline molluscs dated as young as $5.314 \mathrm{C}$ ky BP [44,45], suggesting an erosional event. The Bosphorus strait multibeam bathymetric data (Figure 2) revealed that the upper portions of the deeper channel deposits are composed of parallel layers, which were mainly eroded after their deposition [10]. The last erosion surface corresponds to the bottom of the strait, and the volume of eroded material is estimated at $2.108 \mathrm{~m}^{3}$ and $\mathrm{km}^{3}$. Such volume of eroded material excavated from the Bosphorus Strait is comparable in magnitude to the volume of material constituting the fan. The present day seafloor morphology indicates that the direction of the flow at the origin of this erosion was from the south to the north. The latest morphology of the strait floor was established at about 5-4ky BP. by the Mediterranean bottom current of the modern two-way flow system [10].

\section{Oceanographical setting}

Previous studies, aforementioned, indicate that the prominent cut channel of the shelf fan is directly connected to the Istanbul Strait. This channel turns abruptly northwest when it reaches the mid-shelf of the Black Sea and the stream is deflecting to the left. This is in contradiction with the theory demonstrating that geostrophic currents exiting an outlet in the northern hemisphere and flowing on a sloping sea-floor are deflecting to the right. But no observation was presently able to recognise a Mediterranean plume flowing eastward of the Bosphorus Strait outlet. On the other hand, Stanev (2005) and Stanev et al. (2011) [46] have clearly evidenced a plume persistently flowing northwestwardly within the Black Sea shelf.

Today concerning the surface water circulation, the Black Sea is divided into two basins characterised by two large anticlockwise cyclonic central gyres. These gyres are marked out by a wind-driven current flowing around the whole basin, along the continental shelf edge and above the continental slope [47]. Such anticlockwise "Rim current" flows eastward along the coast of Anatolia on the South western Black Sea shelf in separating anticyclonic coastal eddies from the central basin cyclonic gyres [48-50] (Figure 4). The basin-scale model "Black Sea Physics Analysis and Forecast" from MyOcean catalog (http://marine. copernicus.eu/) can be used for continuous analysis and forecast of the Black Sea circulation and stratification. The model output reveals strong mesoscale eddies playing an important role in the sediment transport from coastal zones to deep water (the mean rim current is represented Figure 4). For instance, several anticyclonic eddies of interest for this study were described near the coast. Particularly, the sub-basin scale eddies located near the Bosphorus strait outlet and along the Crimean Peninsula play an important role in the present day sediment dynamic. The ARGO float profile data published by Stanev et al. [51] indicate that the current velocity measured at $200 \mathrm{~m}$ depth along the "Rim Current" is about $15 \mathrm{~cm} . \mathrm{s}^{-1}$ and decreases to $5 \mathrm{~cm} . \mathrm{s}^{-1}$ at depths of $750 \mathrm{~m}$ and $1500 \mathrm{~m}$ [52]. This slower deeper current closely follows the topography along the Black Sea southern margin. The numerous quasi-permanent coastal eddies described outside the "Rim Current" (Figure 4) are interpreted to be formed from upwelling and wind stress curl mechanisms occurring along the coastal shelf. These data have also shown strong salinity gradient stem from the contrast between the more saline and denser lower layer and the low salinity surface layer.

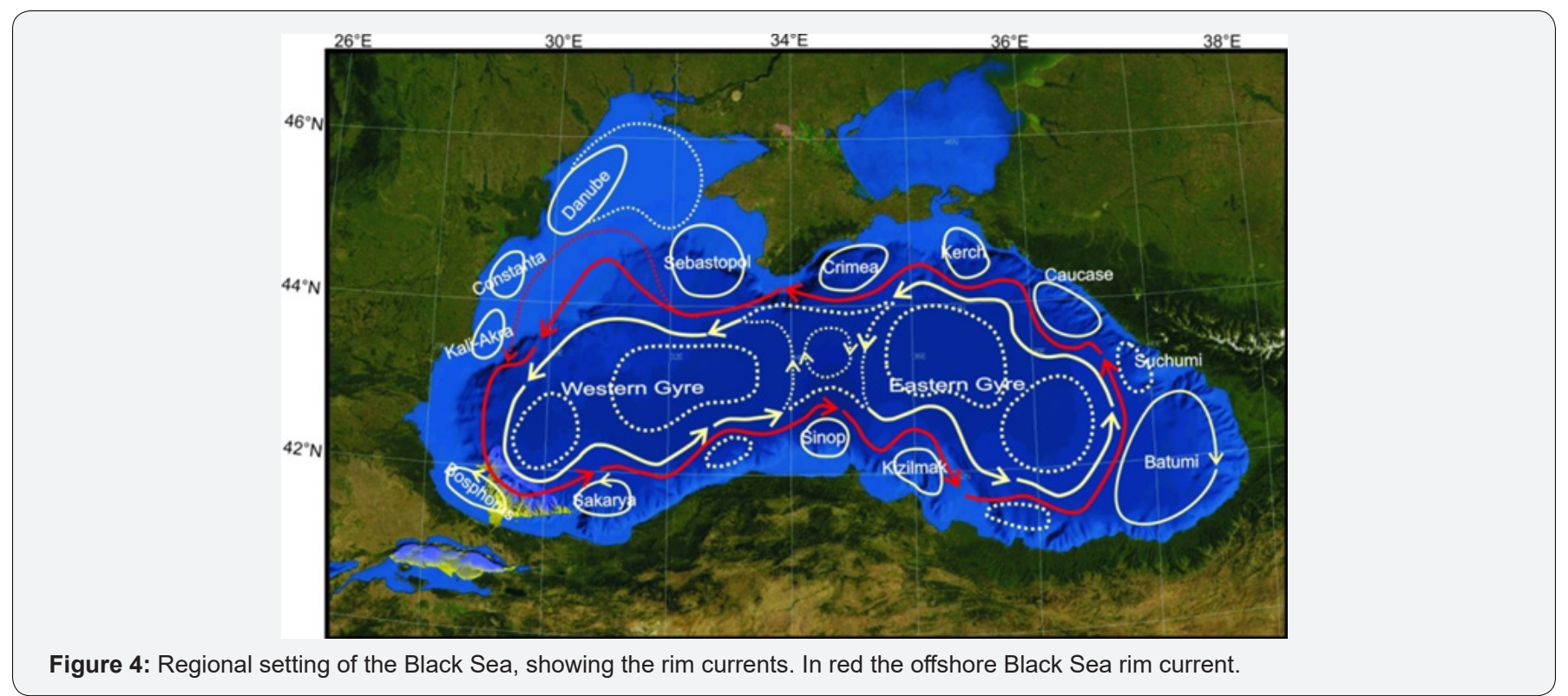


The Black Sea has layers of deep and surface waters that do not intermix and therefore is considered as the largest meromictic basin in the World. The freshwater input to the Black Sea is supplied from smaller rivers such as the north Turkish margin rivers and essentially from large rivers: i.e. the Danube River (ca $200 \mathrm{~km}^{3} . \mathrm{yr}^{-1}$ of mean water discharge) and the Ukrainian rivers Dniepr, Southern Bug and Dniestr (about $65 \mathrm{~km}^{3}$. $\mathrm{yr}^{-1}$ of mean water discharge) [21]. Altogether, the net freshwater input to the Black Sea from the river added to the precipitation is estimated to reach about $300 \mathrm{~km}^{3} \cdot \mathrm{yr}^{-1}$. In addition to this net freshwater inflow, around $300 \mathrm{~km}^{3} \cdot \mathrm{yr}^{-1}$ of higher salinity water is provided by the deep inflow entering the Black Sea through the Bosphorus [53]. This net input is compensated by about $600 \mathrm{~km}^{3}$. $\mathrm{yr}^{-1}$ of low salinity surface water outflowing the Bosphorus to the Marmara Sea [53]. At around 50-150m, the upper and lower water of the Black Sea are separated by a steep density gradient (or pycnocline) originated from the gradual increase of salinity with depth below $200 \mathrm{~m}$. The saline water inflow entering the Black Sea from the Bosphorus mixes with the Cold Intermediate
Layer (CIL) mainly before reaching the shelf break. This CIL located between the pycnocline and the warmer surface water coming from the summer river input, is formed during winters when the upper layer of relatively fresh water of the Black Sea becomes cold. During cold winters more Cold Intermediate Layer water is formed. The outflowing plume out the Bosphorus is mixed downwards and contributes to the deep-water salinity [47].

\section{SW shelf area}

Previous published seismic studies carried out in the Black Sea shelf area indicated a widespread shelf-crossing erosional surface $[7,23,28-34,39,54-56]$, extending to the shelf edge at about $90-120 \mathrm{~m}$ water depth. This erosional surface " $\alpha$ " ( $\alpha$ and $\alpha 1$ terms are from Aksu et al. [23] is almost flat and corresponds to subaerial exposure of the shelf during Pleistocene lowstand stages of the Black Sea. The sediments unconformably deposited over this " $\alpha$ " surface have been defined as Unit 1 . Underneath the " $\alpha$ " surface, four units are recognized: Unit 2, 3, 4 and 5 (Figure 5) $[7,23]$.

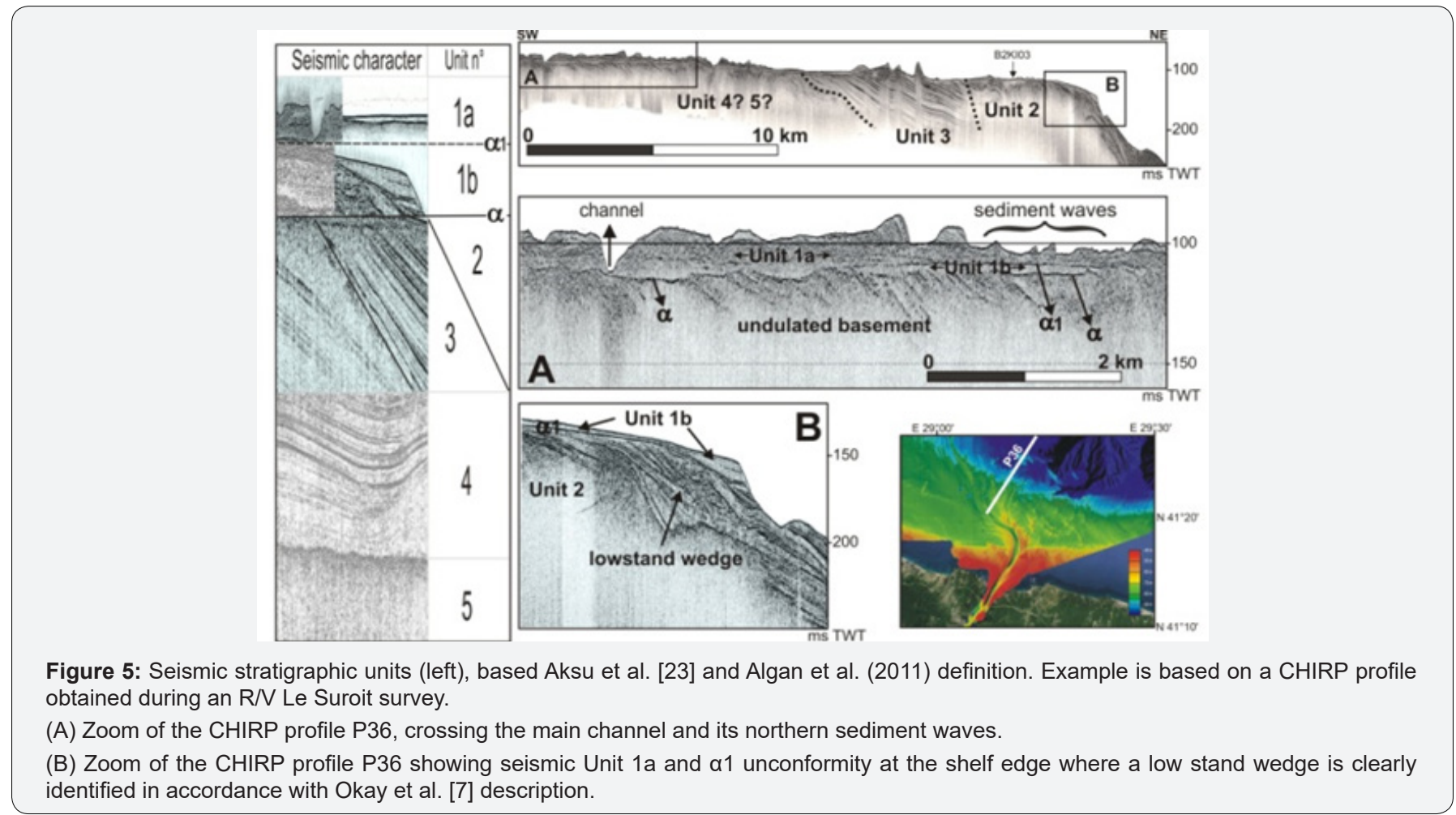

Unit 1 lying above $\alpha$ surface and divided into two subunits, $1 \mathrm{~b}$ and $1 \mathrm{a}$, has been described by Aksu et al. [23]. Subunits, $1 \mathrm{~b}$ and $1 \mathrm{a}$ are separated by the second discontinuity surface, $\alpha 1$ (Figure 5). These subunits have been interpreted by Aksu et al. [23] as lowstand, transgressive and highstand systems tracts deposited during the last glacial low stand and Holocene by a gradual sea level rise beginning $\sim 11^{14} \mathrm{C}$ ky BP. Such relatively thick deposits with parallel and almost even reflections, including prograding clinoforms are also observed off the Sakarya River in the southern Black Sea shelf [54].

\section{Data Collection}

\section{Bathymetrical data}

Data completing the Bosphorus outlet survey (A, B, D areas on Figure 1) are derived from Multibeam bathymetric data collected:

a) On board of RV Le Suroit, in 2002 using a SIMRAD-EM 300 echo-sounder with a $300 \mathrm{kHz}$ frequency and a single Mills Cross array geometry. Swath widths are selectable using either 111 (shallow mode) to 135 beams. The EM 300 system operates from 10 to $5000 \mathrm{~m}$ of water depth with an 
optimum use between $30 \mathrm{~m}$ and $500 \mathrm{~m}$. This bathymetric data set was processed, using Ifremer "Caraibes" and "Globe" softwares. Contour extraction, "spline" curves and bi-dimensional digital filtering were applied to remove multibeam artifacts (C on Figure 1).

b) On board of RV K. Piri Reis with a SeaBeam 1050D echosounder having a frequency of $180 \mathrm{kHz}$ and providing 126 beams. Data processing was also performed with Ifremer "Caraibes" and "Globe" softwares and compiled with the other bathymetrical data (E and F on figure 1).

\section{High resolution seismic data (CHIRP)}

Locations of the seismic profiles used for this study are displayed Figure 6. Two profiles P36 (Figure 5) and P37 (Figure 7), were shot during BlaSON 2 survey [57] using the hull-mounted CHIRP sonar single channel of RV Le Suroit. This system has an operating frequency ranging from 1.8 to $5.3 \mathrm{kHz}$ and acquisition was done using a Delph PC based system. Obtained data were processed and presented in envelope traces. Part of profile 36 has been published by Okay et al. [7].

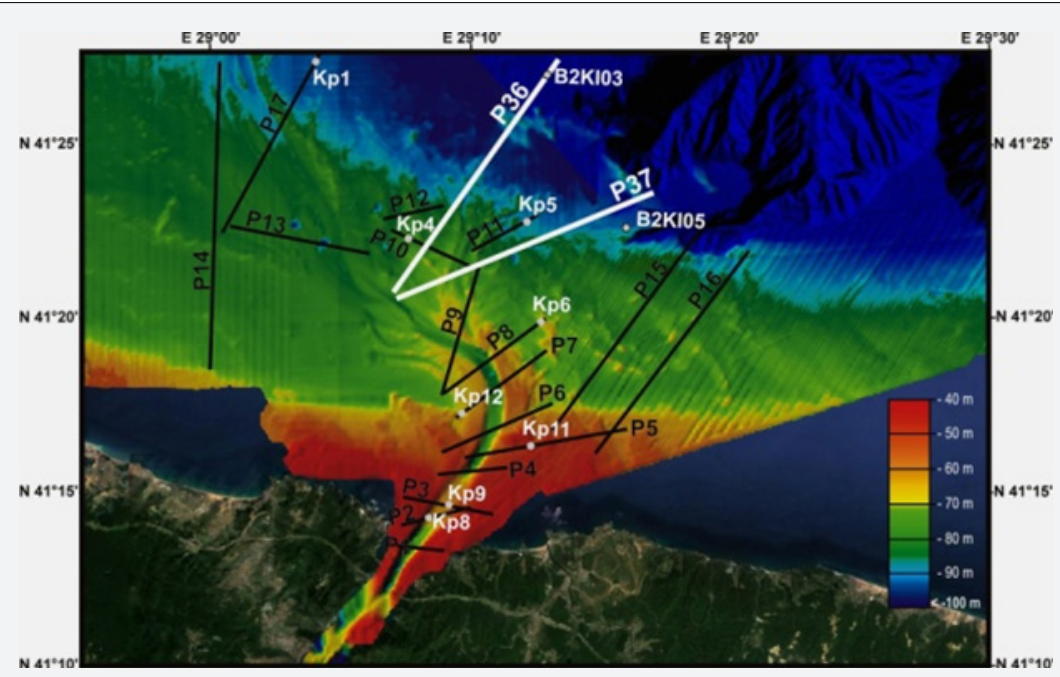

Figure 6: Multibeam bathymetry map of the shelf fan with seismic profile and core location. Solid lines illustrate the high resolution seismic (chirp) profiles (labelled Px) and the star icon shows the location of the cores (labelled Kpx for cores collected by the RV K. Piri Reis during PIA07 cruise and B2KIXX for cores collected during BlaSON2 cruise onboard RV Le Suroît).
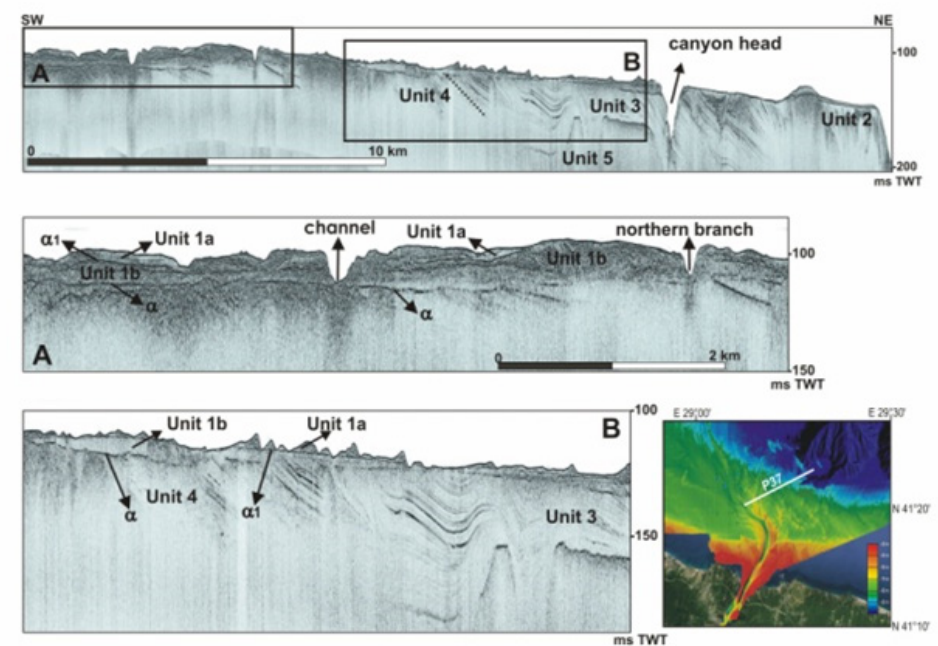

Figure 7: CHIRP profile P37 collected during BlaSON2 survey on the shelf to the shelf-break in front of the Bosphorus Channel. This profile completes the study published by Okay et al. [7] on the seismic stratigraphy.

SeaBed 3010 and Bathy 2010 CHIRP sub-bottom profilers were used on board the R/V K. Piri Reis during cruises in 2007 and 2008, respectively. The Seabed Model 3010 is a threechannel acoustic profiling system offering three transmitting frequency ranges: 3 - 7Khz, $10-14 \mathrm{kHz}$ and $200 \mathrm{kHz}$. The system was deployed using the first mode. Bathy 2010 system has 9 transducers with a sweep frequency from 2.75 to $6.75 \mathrm{kHz}$ and performs real time heave corrections. Collected data were band pass filtered and illustrated as amplitude envelopes. 


\section{Sediment cores}

We studied thirteen gravity cores collected on board the $R / V$ K. Piri Reis and the R/V Arar (Istanbul University, Institute of Marine Sciences and Management) and labelled Kpx, and two box-cores (labelled B2KIxx) recovered by the $R / V L e$ Suroit. Core coordinates, length and water depth at location are presented in Table 1. The gravity cores and the box corers were photographed and lithological described. Subsequently, seven cores (Kp1, Kp4, Kp5, Kp11, Kp12, B2KI03 and B2KI05) (Figure 8) were systematically sub-sampled at $2 \mathrm{~cm}$ intervals. For benthic foraminiferal analysis, samples every $10 \mathrm{~cm}$ were selected and for each sample about $10 \mathrm{~g}$ of dried sub-samples were soaked in water for 24 hours, and then wet sieved through a $0.063 \mathrm{~mm}$ sieve. The residue was dried in air and split with a microsplitter, where foraminifers were abundant, until a subsample containing minimum 300 benthic foraminifer specimens was obtained. In the case of low density (less than 300 specimens), the total residue were examined. All the benthic foraminiferal specimens were identified and counted under a binocular microscope. Age determination of selected mollusc samples was carried out by radiocarbon dating at the Isotope Geochemistry Laboratory of Arizona University and Geochrone Laboratory (USA) (Table 2). For Table $2,{ }^{14} \mathrm{C}$ ages are calibrated using IntCal13 [58] and program Calib Rev 7.0.4 [59]. Reservoir age is assumed to have been constant to $415 \pm 90{ }^{14} \mathrm{C}$ yrs [60] through the Holocene. Nevertheless, all ages reported in the text are uncalibrated radiocarbon dates with no reservoir correction, in order to compare with previous works in the area.

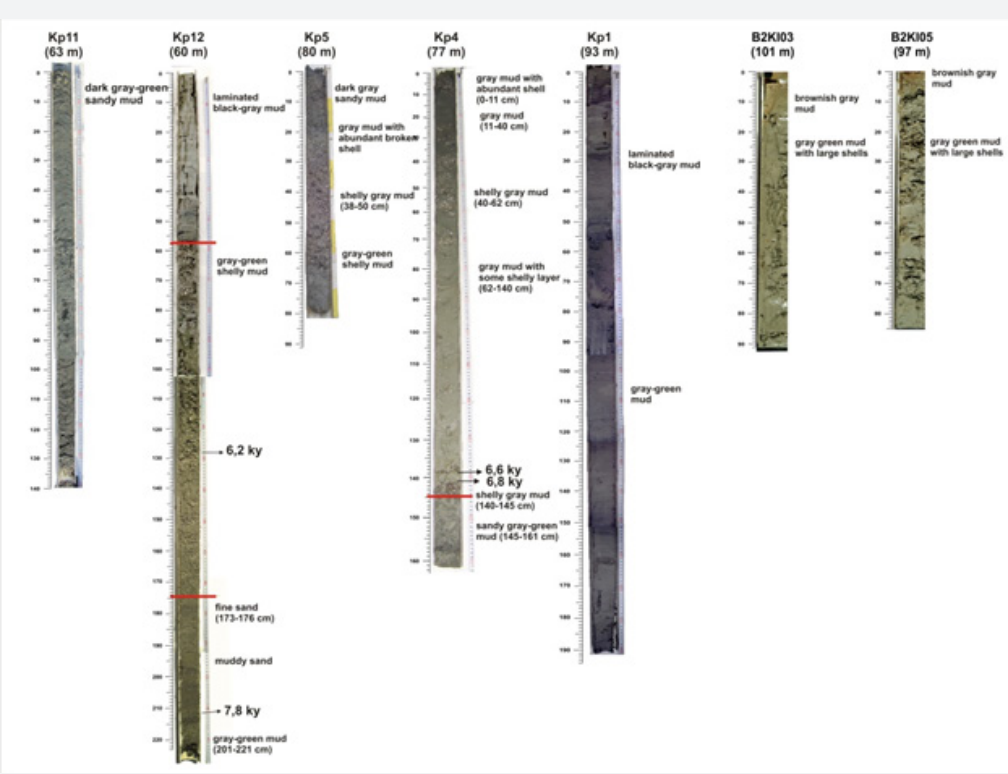

Figure 8: Core photographs. Location of cores is given figure 6 and position on seismic profiles figure 5, 8 and 9. Coordinates, water depth and length are given in Table 1. Water depth $(\mathrm{m})$ of cores is given within parentheses below the core labels. Red lines indicate sharp lithological boundaries within the cores. Ages are indicated by "ky" corresponding to ${ }^{14} \mathrm{C}$ age BP. Correspondence to Calibrated yr BP is given in Table 2.

Table 1: Location of the cores, water depth at location and length of the cores.

\begin{tabular}{|c|c|c|c|}
\hline Core No & Location & Water Depth (m) & Core Length (cm) \\
\hline Kp1 & $41^{\circ} 28^{\prime} 22.9476^{\prime \prime} \mathrm{N} / 29^{\circ} 5^{\prime} 4.506^{\prime \prime} \mathrm{E}$ & 92.8 & 188 \\
\hline Kp4 & $41^{\circ} 21^{\prime} 54.5106^{\prime \prime} \mathrm{N} / 29^{\circ} 8^{\prime} 27.7584^{\prime \prime} \mathrm{E}$ & 76.9 & 75 \\
\hline Kp5 & $41^{\circ} 21^{\prime} 32.7774^{\prime \prime} \mathrm{N} / 29^{\circ} 11^{\prime} 13.8762^{\prime \prime} \mathrm{E}$ & 80.2 & 5 \\
\hline Kp6 & $41^{\circ} 19^{\prime} 9.7026^{\prime \prime} \mathrm{N} / 29^{\circ} 11^{\prime} 17.9772^{\prime \prime} \mathrm{E}$ & 66.9 & - \\
\hline Kp8 & $41^{\circ} 14^{\prime} 12.0006^{\prime \prime} \mathrm{N} / 29^{\circ} 8^{\prime} 14.9994^{\prime \prime} \mathrm{E}$ & 50 & - \\
\hline Kp9 & $41^{\circ} 14^{\prime} 24^{\prime \prime} \mathrm{N} / 29^{\circ} 10^{\prime} 3.6012^{\prime \prime} \mathrm{E}$ & 43 & 133 \\
\hline Kp11 & $41^{\circ} 17^{\prime} 2.3994^{\prime \prime} \mathrm{N} / 29^{\circ} 11^{\prime} 48.0012^{\prime \prime} \mathrm{E}$ & 63 & 220 \\
\hline Kp12 & $41^{\circ} 17^{\prime} 4.8006^{\prime \prime} \mathrm{N} / 29^{\circ} 9^{\prime} 27.6012^{\prime \prime} \mathrm{E}$ & 60 & 90 \\
\hline B2KI03 & $41^{\circ} 27^{\prime} 1.9794^{\prime \prime} \mathrm{N} / 29^{\circ} 13^{\prime} 27.4794^{\prime \prime} \mathrm{E}$ & 100.6 & 97 \\
\hline B2KI05 & $41^{\circ} 22^{\prime} 19.776^{\prime \prime} \mathrm{N} / 29^{\circ} 16^{\prime} 19.1994^{\prime \prime} \mathrm{E}$ & & 93 \\
\hline
\end{tabular}




\section{International Journal of Environmental Sciences \& Natural Resources}

Table 2: Radiocarbon dates obtained from mollusc samples.

\begin{tabular}{|c|c|c|c|c|}
\hline Core No/Interval (cm) & Material & ${ }^{14} \mathrm{C}$ Age BP & ${ }^{14} \mathrm{C}$ Age BP Corrected for Reservoir Age1 & Calibrated yr BP $(1 \sigma)^{2}$ \\
\hline Kp12/128-130 & Mytilus & $6155 \pm 090$ & $5740 \pm 130$ & $6402-6673$ \\
\hline Kp12/211-214 & Dreissena & $7795 \pm 140$ & $7380 \pm 165$ & $8036-8345$ \\
\hline Кр4/138-141 & Mytilus & $6595 \pm 100$ & $6180 \pm 135$ & $6930-7252$ \\
\hline Кр4/142-145 & Broken Mytilus shells & $6830 \pm 085$ & $6415 \pm 125$ & $7241-7565$ \\
\hline
\end{tabular}

a) Reservoir age is assumed to have been constant to $415 \pm 9014 \mathrm{C}$ yrs [60] through the Holocene

b) $\quad{ }^{14} \mathrm{C}$ ages corrected for reservoir age were calibrated using IntCal13 [58] and program Calib Rev 7.0.4 [59].

Results

\section{Bosphorus outlet morphology}

The morphological features observed in the study area are briefly defined from the bathymetrical map (Figure 1) and discussed together with the high resolution CHIRP profiles. From a physiographical point of view; the study area can be defined into two parts: (1) the Bosphorus Channel, and (2) the Shelf area.

\section{Bosphorus channel}

The Bosphorus channel at the outlet of the Istanbul Strait is incised to a depth of about $-85 \mathrm{~m}$, as a narrow ravine and extends into the inner shelf (Figure $1 \& 2$ ). A sill with elliptical shape located at a depth of $-60 \mathrm{~m}$ within this ravine has a length of $4.2 \mathrm{~km}$. The channel extends $8 \mathrm{~km}$ along N-NE direction, turns sharply to NW direction. From the abrupt bend, it is divided into branches with a prominent one flowing northward to the shelf edge. There are short branches to NW and N-NE. The N-NE trending branch is bifurcated, terminating at about $-90 \mathrm{~m}$. It is blocked by levees and hence, it might have been formed before the main channel (avulsion). The channel becomes shallower and is carved into shallower depths, about 1 to $3 \mathrm{~m}$ deep from mid-shelf to shelf edge. Flow traces and small bars can be noticed in this shallow NW extension of the channel. Okay et al. [7] have described these branches according to their formation/activity order. Levees occur at both sides of the channel, particularly after its sharp turn to NW direction, from -60 to $-70 \mathrm{~m}$ water depths.
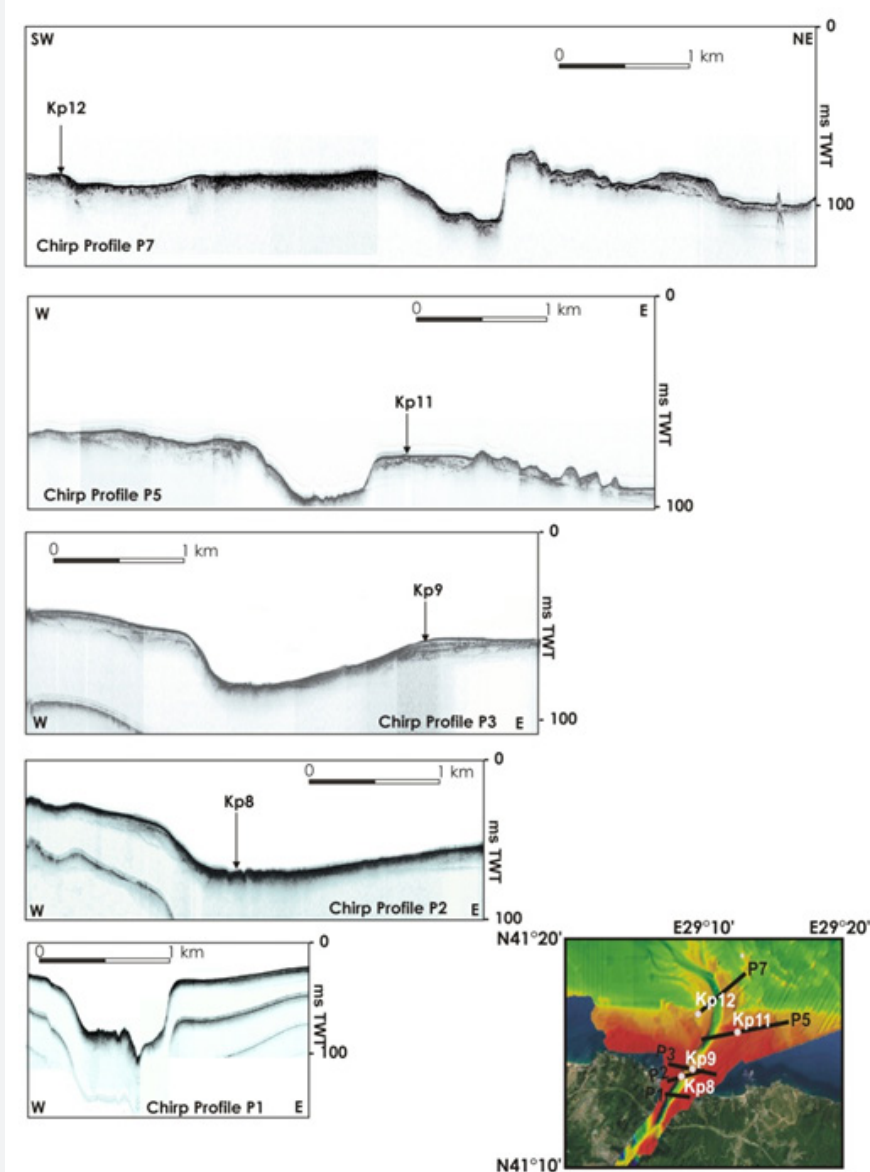

Figure 9: CHIRP profiles $\mathrm{P} 1, \mathrm{P} 2, \mathrm{P} 3, \mathrm{P} 5$ and $\mathrm{P} 7$ collected across the shallow fan, showing evolution of the depth and shape of the main channel from the Bosphorus outlet to the offshore. Location of these profiles is given in this figure and figure 6 . 
Seismic profiles indicate that the channel axis has irregular topography and an asymmetrical profile, from the outlet of Istanbul Strait to its sharp turn to NW (Figure 1). The western side of the channel bottom becomes deeper. The banks along the channel at -20 to $-45 \mathrm{~m}$ water depths have in general, acoustically weak reflections (Figure 9). From seismic profiles P5 to P8 (Figure $9 \& 10$ ), these banks can be seen as rock formations rising to sea floor, particularly at the east side of the channel. Reflections from the channel bottom itself also do not show any sedimentary deposit. The west side levees have some internal reflections and display the same character towards the north. Drapes in both side of the channel characterised by an acoustically transparent thin veneer, are also noticed where the channel shallows (Figure 10). The basement is exposed on the sea floor, indicating the active erosional process of the channel (Figure 10). A conical mound which might be induced by rising gas or mud $[5,23]$ is also found on the right side of the shallow channel (Chirp profile P17, Figure 10).

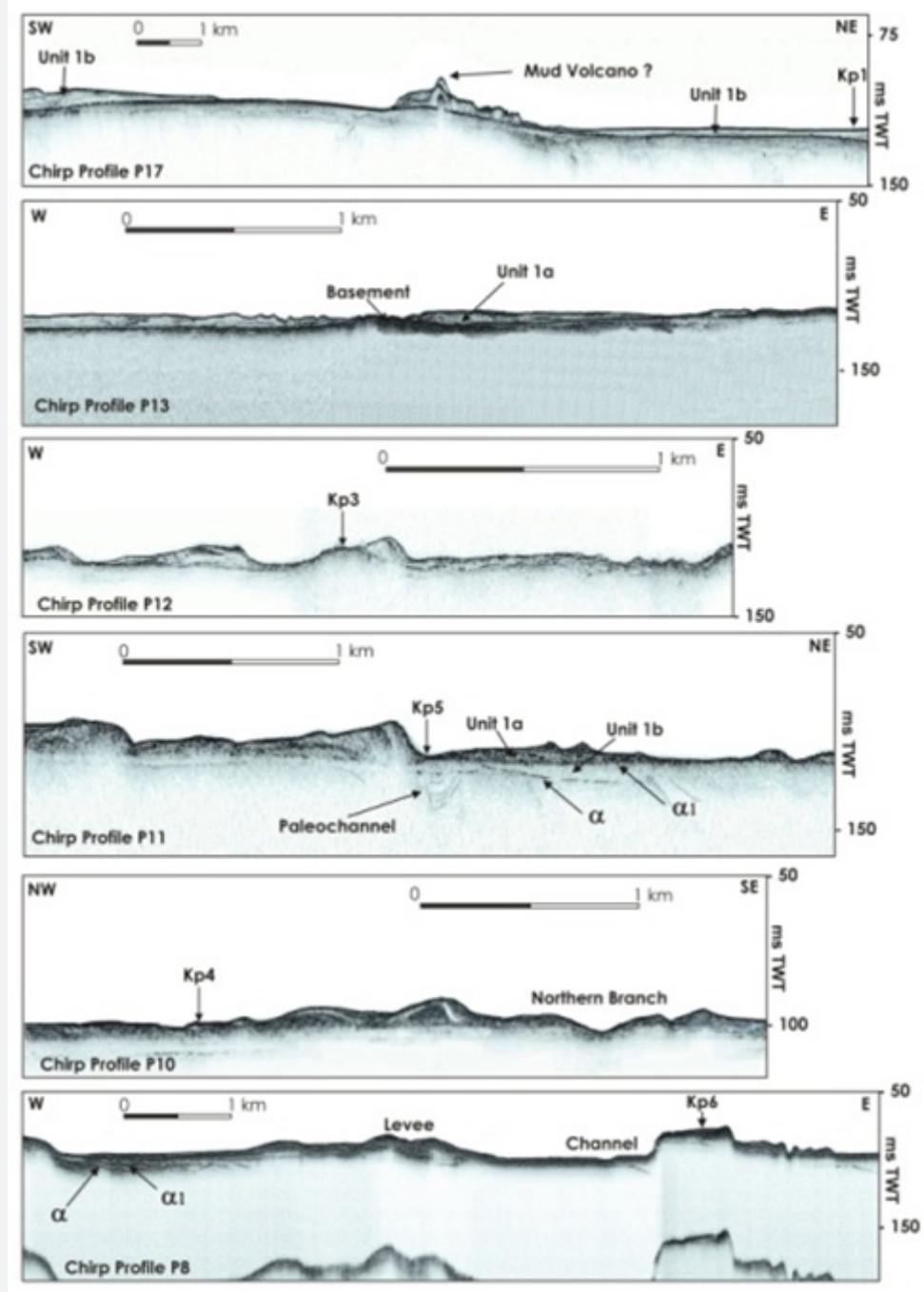

Figure 10: CHIRP profiles $\mathrm{P} 8, \mathrm{P} 10, \mathrm{P} 11, \mathrm{P} 12, \mathrm{P} 13$ and $\mathrm{P} 17$ collected across the middle and distal parts of the shallow fan. Erosional surfaces $\alpha$ et $\alpha 1$ are visible on P8 and P11. Location of these profiles is given figure 6 .

\section{Shelf area}

The shelf area where the channel incised is a smooth plain includes linear bedforms (ridges), sediment waves and conical mounds (Figure 11). The linear bedforms at the east of the channel are ranged in the same direction of the channel at a water depth of $75-80 \mathrm{~m}$. They have 1 to $5 \mathrm{~m}$ heights and $5.5-$ $6 \mathrm{~km}$ lengths. At the west side of the channel, linear bedforms are located at $80-85 \mathrm{~m}$ water depths and slightly curved. They have up to $5 \mathrm{~km}$ length. Apart from these morphological features, small hollows cut to a depth of $90-95 \mathrm{~m}$ are observed at $-85 \mathrm{~m}$ water depth (Figure 11).

The linear ridge-shaped elements at the eastern and western shelf area of the channel appear to be substratum outcropping on the sea floor, and/or accumulating sediments over such 
topographical protrusions (Figure 10 \& 12). The sediment waves in the vicinity of the levees have mostly asymmetrical shape with their steep sides leaning to N-NE (Figures 10 \& 12). They have different heights from the sea floor varying from 3 to $8 \mathrm{~m}$ and present internal stratifications (Figures 5, 7 \& 12).

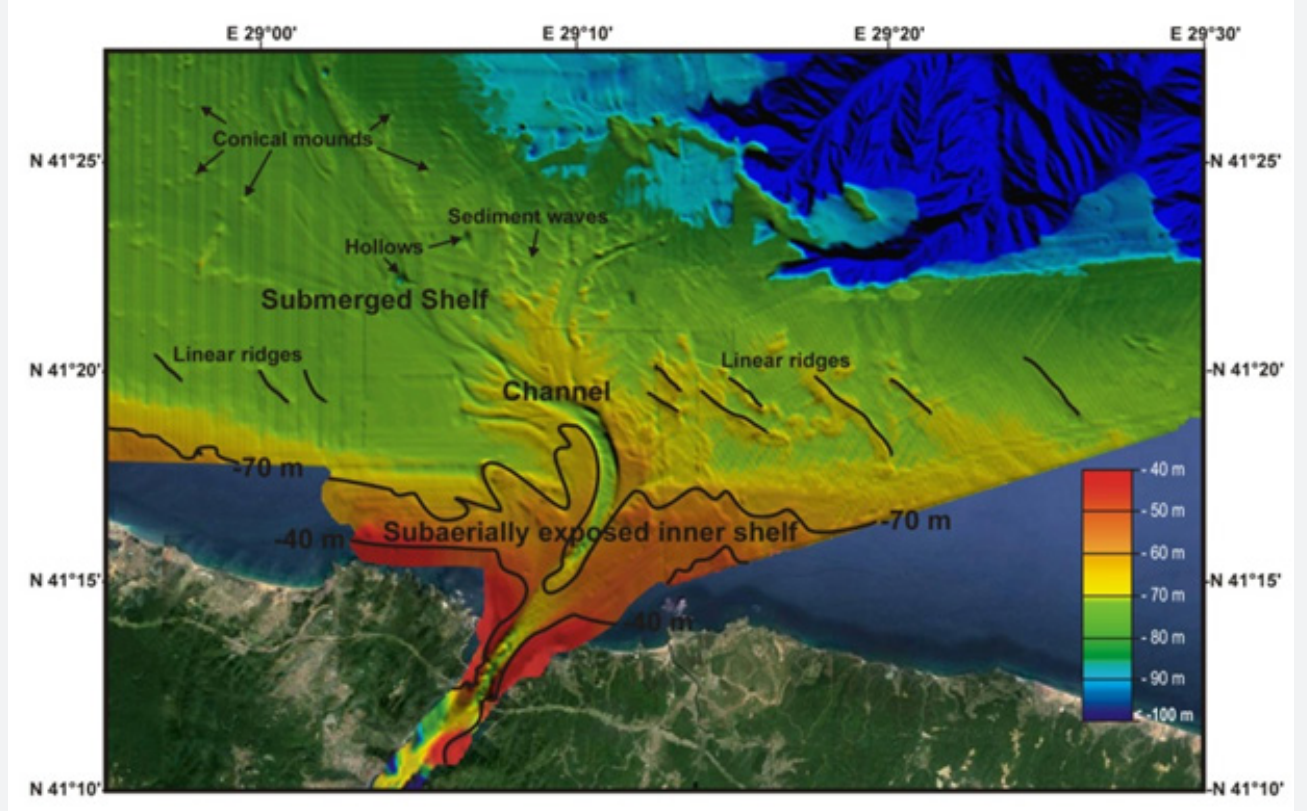

Figure 11: Subaerial and submerged part of the shelf at sea levels of -70 [27] during the last reconnection. A level of $-40 \mathrm{~m}$ [24]is also shown
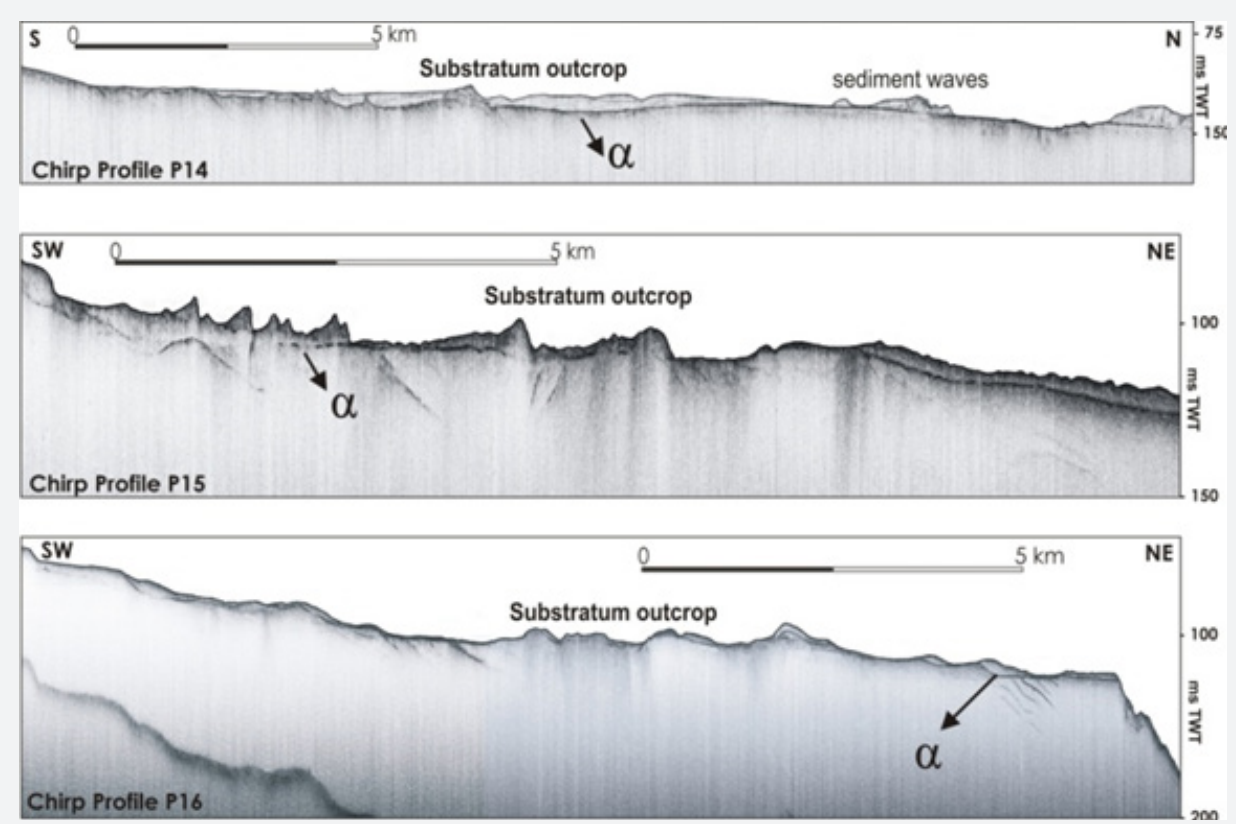

Figure 12: CHIRP profiles $\mathrm{P} 14, \mathrm{P} 15$, and $\mathrm{P} 16$ representing transect profiles obtained on the western and eastern sides of the shallow fan. Erosional surfaces $\alpha$ is visible on the distal part of these profiles. The lineaments outlined on the bathymetric map are related to outcrops of the substratum

\section{Seismic stratigraphy of the SW shelf}

The almost flat widespread shelf-crossing erosional surface here-before mentioned ( $§ 2.3$, surface " $\alpha$ ") is clearly recognized on the profiles of this study. Four to five seismic units are truncated by this unconformity (Figure 5). Some specific features are noticeable on the seismic profiles, i.e. Unit 3 is incised by paleochannels. Unit 2 is only observed at the shelf edge. Unit 1 is the youngest unit, deposited above $\alpha$ surface and 
divided into two subunits, $1 \mathrm{~b}$ and $1 \mathrm{a}$. As described by Aksu et al. [23], Unit 1a is clearly separated from Unit $1 \mathrm{~b}$ by the second discontinuity surface, $\alpha 1$ (Figure $5 \& 7$ ). This minor erosional surface " $\alpha 1$ " is observed in the vicinity of the channel and is less apparent, compared to " $\alpha$ " surface. Unit $1 \mathrm{~b}$ is represented by a lowstand shelf wedge (thickness; $20 \mathrm{~ms}$ ) at the shelf edge, deposited over previous wedges (Figure 5B). It has parallel and almost even reflections and is relatively thick, and includes prograding clinoforms. However, it becomes very thin under a chaotic reflection toward the inner and mid-shelf, where it has a limited occurrence (Figure 5A). Unit 1a is defined between $\alpha 1$ surface and present seafloor (Figure 5 \& 7).

The seismic stratigraphical relation of the channel-levee complex can be better seen after its sharp NW turn. Major erosional surface $\alpha$ is mostly flat, but can be undulating too (Figures 5, 7 \& 12). $\alpha 1$ is a local and weak discontinuity and intersects $\alpha$ surface beneath the levees, where the inclined structure of the basement displays irregularities or undulations. Unit $1 \mathrm{~b}$ is very thin and located between these two surfaces, and is absent where two erosional surfaces merge (Figures 5 \& $10)$. However, at the SW outer shelf of this study area, this unit is observed as parallel reflectors. The internal structure of the levees is mainly chaotic, but locally displays inclined reflectors at their top. The maximum thickness occurs near the channel, decreasing slowly with increasing distance from the channel (Figures 5B \& 9).

\section{Sediment data}

\section{Additional information from cores}

The locations of the sediment cores are shown in Figure 6 and Table 1 gives information on their coordinates, length and water depth at each location. Some of the cores did not recover materials due to the nature (sandy and/or substratum) of the sea-bottom. However, these last cores confirm the seismic interpretations.

On the left side of the channel after its sharp bend at a water depth of 63m, Core Kp12 (Chirp Profile 7, Figure 9) recovered the thin sediment layer covering the substratum, corresponding to the weak reflection interpreted on the seismic profile. Core $\mathrm{Kp} 12$ is $220 \mathrm{~cm}$ long and has three different lithological units (Figure 8). From the bottom, there are $20 \mathrm{~cm}$ of gray-green mud in which a Dreissena shell (from $214-211 \mathrm{~cm}$ ) yield an age of $\sim 7.8$ ${ }^{14} \mathrm{Cky}$ BP (Table 2). In the interval from 200 to $173 \mathrm{~cm}$, silt and sand content increases. At $173 \mathrm{~cm}$ there is a sharp boundary and above the discontinuity a gray-green shelly mud continues until $58 \mathrm{~cm}$. A Mytilus shell from this layer $(130-128 \mathrm{~cm})$ was dated to $\sim 6.2{ }^{14} \mathrm{C}$ ky BP (Table 2). The top $58 \mathrm{~cm}$ is laminated black-gray mud, Core Kp5 was collected from a water depth of 80m (Chirp Profile P11, Figure 10), next to a sediment wave and above the $\alpha 1$ surface. From the bottom, $75 \mathrm{~cm}$ to $50 \mathrm{~cm}$ a gray mud with large shell characterises the lithology. Above $50 \mathrm{~cm}$ mud with abundant shell fragments occurs up to $20 \mathrm{~cm}$. The uppermost
$20 \mathrm{~cm}$ contains dark gray mud with fine sand (Figure 8).

Core Kp4 was recovered from $77 \mathrm{~m}$ depth over a small sediment wave (Chirp Profile P10, Figure 10). It consists of $14 \mathrm{~cm}$ of sandy mud at the bottom overlapped after a sharp boundary by $145 \mathrm{~cm}$ of gray-green mud with occasional shells and shell fragments. Two ages obtained at $141-138$ and $145-142 \mathrm{~cm}$ gave ages of 6.8 and $6.6^{14} \mathrm{C}$ ky BP (Table 2).

Cores Kp8 and Kp9, respectively recovered in the Channel and on the lee side of the channel at the outlet of the strait (Figures $9 \& 10$ ), recovered only a small amount of sand. Core $\mathrm{Kp} 11$ (133cm of recovery) realised in $60 \mathrm{~m}$ of water depth and located at the right side of the channel (Figure 9, profile P5) consists of gray-green sandy muds (Figure 8). This layer is the thin sediment cover over the substratum, interpreted from Chirp profile P5 (Figure 9). Core Kp6 on the right side of the channel (Chirp Profile P8, Figure 10) has only $5 \mathrm{~cm}$-length and consists of sand. These cores could not penetrate further into the substratum.

Core Kp3 (Chirp Profile P12, Figure 10) recovered only a small amount of shell hash, probably reflecting the erosional surface.

Core Kp1 represents the thin veneer (Unit 1b) from $93 \mathrm{~m}$ water depth above the erosional surface $\alpha$ (Chirp Profile P17, Figure 10). The lowermost $100 \mathrm{~cm}$ is gray-green mud gradually changed upward in a laminated black gray mud (Figure 8).

Short box cores collected during BlaSON 2 survey: B2KI03 and B2KI05 ( $\sim 80 \mathrm{~cm}$ of length, Figure 8 ) all consist of gray green mud, including large Mytilus shells and their fragments.

\section{Benthic fauna}

Benthic foraminiferal assemblages within core Kp12 follow more or less the lithological boundaries (Figure 13). Total benthic foraminifera density (TBF) is low from the bottom of the core until $\mathrm{cm} 125$ where it first increases between 120 to 110 , followed by a second higher peak between 80 to $60 \mathrm{~cm}$ (Figure 13). The uppermost laminated black-gray mud contains the lowest total benthic foraminifera density and poor diversity. Foraminifera diversity decreases from the bottom to the top of the core. Common species in the lower part of the core are Bulimina aculeata, Lobatula 1obatula, B. elongata, Elphidium pauciloculum, Elphidium spp., Brizalina spp., Haynesina anglica and H. depressula.

Ammonia is the dominant genus (70-90\%) with A. compacta, A. tepida, and A. parkinsoniana. In the lower part of the core, up to $140 \mathrm{~cm}, A$. tepida and A. parkinsoniana are relatively abundant compared to the other species. A. tepida is dominant in the lower part of the core, whereas $A$. compacta is higher from 80 to $60 \mathrm{~cm}$.

This assemblage change is also observed in mollusc (pelecypoda) fauna. A fresh-brackish form, Dreissena, and juvenile euryhaline molluscs are found together below $140 \mathrm{~cm}$, whereas only 
Mytilus shells are found above this level. The lowermost $80 \mathrm{~cm}$ of the core represents the transition from fresh-brackish to marine conditions, based on changing mollusc fauna.

Ammonia genus is also the most common benthic foraminifer in core Kp4 (52-95\%). Total benthic foraminifera display a significant increase at $\sim 60-75 \mathrm{~cm}$ interval with dominant $A$. compacta, and followed by A. parkinsoniana and A. tepida. This interval corresponds to $\sim 3.5 \mathrm{ky}$ BP (extrapolating from dates in Table 2). E. pauciloculum, L. lobatula, H. depressula, E. macellum, Quinqueloculina seminula, Eggerella scabra and Elphidium spp. occur less than $10 \%$.
In comparison with previous data, benthic foraminiferal abundances of the short box core B2KI03 (Figure 13) are represented by dominant $A$. compacta and lesser occurrence of $H$. depressula, A. parkinsoniana, A. tepida, Porosononion subgranosum, E. macellum, E. pauciloculum, Quinqueloculina laevigata, Q. seminula, Pyrgo elongata (Figure 13). Core B2KI05, which was analysed and the results published by Kirci-Elmas et al. [61], show a higher diversity (number of species: 2543) compared to other cores and its total benthic foraminifera reduce at the upper parts of both cores.

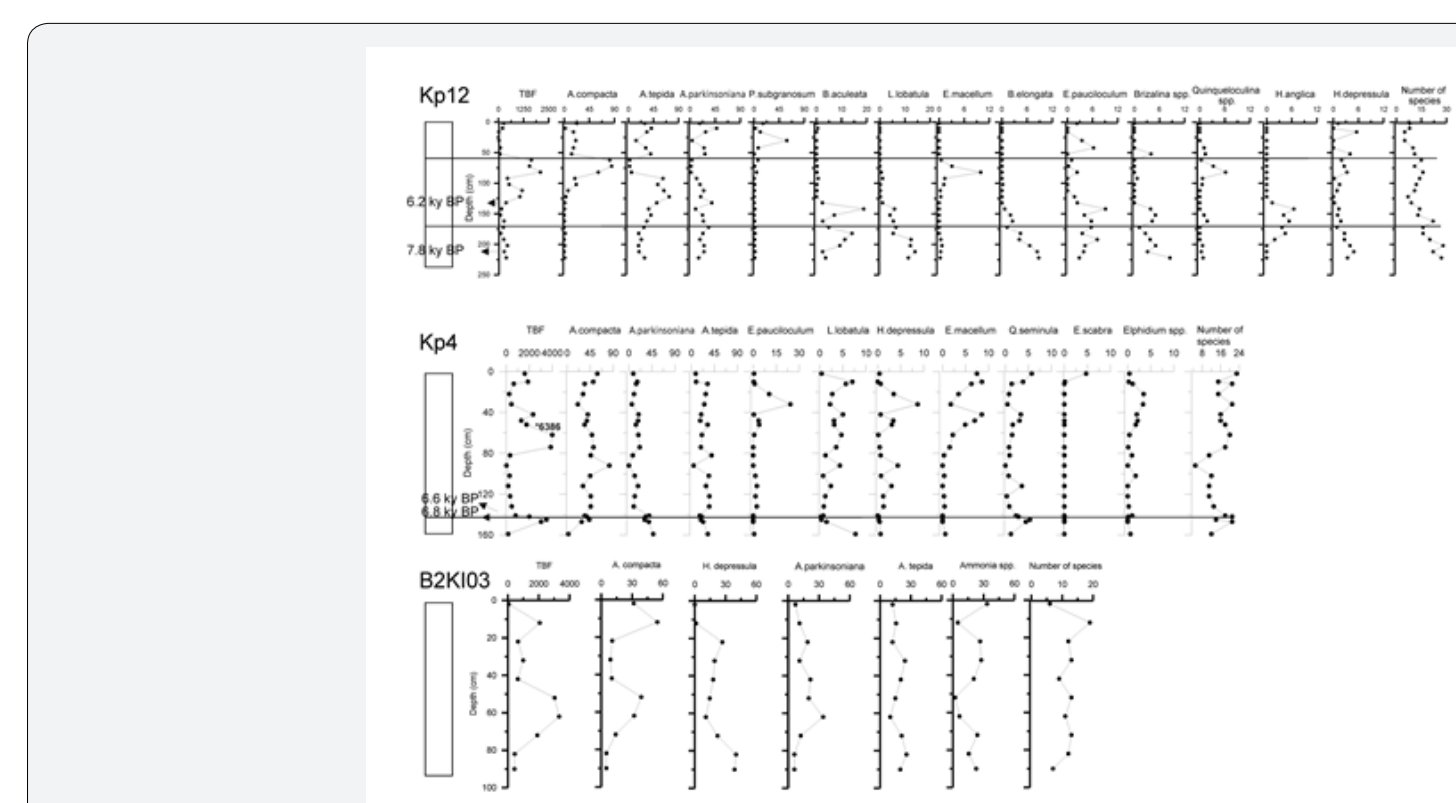

Figure 13: Downcore distribution of benthic foraminifers, in order of abundances. $X$ axis indicates the percentage of the species. Horizontal lines denote the lithological boundaries. $\left(\mathrm{TBF}=\right.$ total benthic foraminifera; ${ }^{*}=$ Specimen number of only indicated sample is independent from the scale)

\section{Discussion}

Previous studies, mentioned above, indicate that a prominent cut channel on the seabed has a direct connection with the Bosphorus outlet. This channel turns abruptly northwest when reaching the Black Sea mid-shelf, but in the northern hemisphere, the theory of geostrophic currents demonstrates that the stream exiting the strait and flowing on a sloped bottom should have deflected to the right. Today, all observation carried out in this area have failed to trace the plume of the incoming water from the Marmara Sea flowing eastward. For instance, Stanev et al. [12] \& Stanev [46] have clearly evidenced a persistently northwestward plume within the shelf.

Di Iorio and Yüce, Latif et al., Oguz et al. \& Yuce $[1,2,49,62]$ have initially proposed that the deflection to the left of the plume could be the result of a guidance from the narrow underwater channel. As already mentioned, this deflection could be related with the anticlockwise rotating 'Rim current' flowing eastward along the Turkish coasts. The anticyclonic coastal eddies are consequently separated from the cyclonic gyres located in the center of the basin [48-50] (Figure 4). In the present study, the seafloor morphology confirms that after the plume reaches the continental slope, it turns to the left, and when reaching the shelf break, entrainment dominates the plume dynamics leaving very little propagation along the slope.

\section{A shallow fan}

Submarine channels in lakes, seas or open oceans can often be kilometres wide extending for thousands of kilometres across the seafloor and reaching hundreds of metres deep. Their formation results from underwater flows of density currents along the sea floor; like lake water, water denser than sea water or by flows of sand or mud. These channels correspond to the main transport pathway to the deep for moving sediments and are very important as they form large deposits of sediments. Today, laboratory experiments are manly the only way to understand such flow processes and the knowledge of their deposits is obtained from ancient examples now exposed on land or from recent analogue studies like this study. 
Holmes \& Nemec and Steel $[63,64]$ have defined a "Fan delta" :"a prism of sediment, delivered by an alluvial fan, and deposited mainly or entirely subaqueously at the interface between the active fan and a standing body of water". Such depositional systems are produced in both low and high energy conditions, containing coarse and fine-grained deposits, erosional bedforms (chutes, flutes) and hence are related to episodic events occurring under both riverine and submarine processes [65,66]. Modern fan delta formations are found in general, in front of tectonically active coasts with high relief, and on wave-dominated shelves $[63,66]$ and also can be formed with a sudden catastrophic flood $[67,68]$. The seismic stratigraphical relations together with the morphology indicate that the present extension of the channel on the shelf area and associated sedimentary depositions are geologically very young and were developed by a relatively fast process, as they were well preserved [39]. This does not imply to the origin of the Istanbul Strait itself, which dates back to Pliocene [11,42] Incised and filled paleochannels observed in older units below $\alpha$ (Figures $7 \& 9$ ) surface suggest a slightly different route or routes than that of present, during Pleistocene glacial periods [7]. The rock formations exposing on the sea floor on the east side of the channel (Figure 9) might have caused the channel to redirect its route from NE to NW. Around N41 $29^{\prime}$ and E $29^{\circ} 02^{\prime}$ (Figure 1), mid-channel islands are recognizable, whilst Hiscott et al. [6] have described modern day surficial sediment processes evidence, these islands display classic lemniscate or tear-drop morphology and are generally formed during highmagnitude water flow $[69,70]$.

The presented fan delta defined previously by Giosan et al. [24]; "Bosphorus-shelf fan") and Okay et al [7]; "shelf fan") consists of a channel with asymmetrical section and is relatively wide at the strait outlet, presenting levees located on its both sides where some avulsion channels cut previous levees, downstream. The levees are characterized by mostly chaotic seismic reflectors. These relatively thicker deposits are accumulated along the main channel, decreasing their thickness away from the channel. Asymmetrical sediment waves occur mainly on the right side of the channel. As the channel becomes shallower and branches towards the north, levees appear to be cut by the active channel and its short branches (distributaries) [7].

Core data shows that the proximal area, low amplitude regions of the fan (channel outlet) are eroded to the substratum and/or overlaid by coarse grained (sand-rich) sediments. In this area, deposition and/or preservation of mud must have been prevented by the enhanced erosion. Levees and sediment waves probably consist of relatively coarse-grained sediments accompanied by shells, and are capped by mud drape (cores Kp12 and Kp4). At the distal part of the fan, deposition is characterized by high amplitude and continuous seismic character. There are various mud depositions related to lateral accretions and ongoing activity of the channel at the outer shelf [5].
The morphology of this shallow fan system indicates a southern source flowing to north, in other words from Istanbul Strait to the Black Sea shelf area. Division into smaller branches and decreasing channel depth after its sharp bend might be related with the decreasing energy of its erosion. The distal part (mid- to outer shelf) and lateral portions of the proximal part are subject to minor erosion and lower velocities as indicated by the fine-grained sediment deposition (core KP1; Figure 8 \& 10).

\section{Evolution mechanism}

The crucial point of this shallow fan system is its formation in respect to sea level; in other words, whether it has formed subaerially by the abrupt flooding (or catastrophic flooding) of Mediterranean waters [34,39,71], or subaqueously below the Black Sea outflow $[5,23,27]$. If we consider the volume of the fan itself, it can be compared in magnitude to the volume eroded from the entire strait of the Bosporus which is empty of sediments today [8,13]. Ryan et al. [8] proposed that when the Bosphorus sill was breached by the Mediterranean waters, the resulting outburst of saltwater, gaining energy when enlarging the inlet was responsible of the onset of this depositional fan, thus fed from the Strait of Istanbul. Since this system was developed above the both erosional surfaces $\alpha$ and $\alpha 1$, the origin of the younger surface; $\alpha 1$ signifies the effective processes on its formation. The origin of the $\alpha 1$ surface was shown to have formed by subaerial exposure [23], but later revised to a subaqueous erosion in Early Holocene by Hiscott et al. [27]. They indicated a continuous sedimentation during the last $9.314 \mathrm{C}$ ky BP without a hiatus at $\alpha 1$ from a core collected at a depth of $-69 \mathrm{~m}$, from $\sim 70 \mathrm{~km}$ west of the Bosphorus. This erosion was either due to the entrance of the Mediterranean inflow into the Black Sea, or beneath an early and vigorous Rim Current. The evolution of the channel and its associated sedimentary bedforms were shown to have occurred under entirely subaqueous conditions by Flood et al. [5], following the interpretation of $\alpha 1$ surface by Hiscott et al. [27]. However, they showed local erosional truncation at $\alpha 1$ in the outer shelf and a hiatus between 10 and 8.2 14C ky BP (from their Figure 12) at a water depth of $91 \mathrm{~m}$. This observation is concordant with the dunes on the desiccated north-western Black Sea outer shelf at about 80-100m water depth which had formed between 10 and $8.514 \mathrm{C}$ ky BP $[15,16]$. The occurrence of buried, small incised valleys and preservation of these sand dunes covered by a marine mud drape characterise a rapid transgression leaving no time to ravinement processes related to the rise of the water level to erode significantly the seafloor. This last pre-Holocene lake level fall was estimated at $-100 \mathrm{~m}$ by Lericolais et al. [15,30-32] on the NW shelf, implying a rapid transgression, whereas $-40 \mathrm{~m}$ by Giosan et al. [24] off Danube delta and at $-70 \mathrm{~m}$ by Hiscott et al. [27] on the SW shelf. Parallel bedding above $\alpha$ surface $[5,23,26]$ indicate a more gradual transgression after the described low stand. Numerous conical mounds are located mainly in the west side of the channel at the outer shelf. Most of them were described as mud volcanoes [5,7], 
but can also correspond to sediment waves similar to the ones that are located perpendicular to the bifurcated N-NE branch. Apart from these morphological features, small hollows cut to a depth of $90-95 \mathrm{~m}$ are observed at $-85 \mathrm{~m}$ water depth. These hollows are expressions of scouring over exposed basement ridge as indicated by Flood et al. [5].

\section{Stratigraphy of the south-western shelf}

The almost flat widespread shelf-crossing erosional surface here-before mentioned ( $\$ 2.3$, surface " $\alpha$ "), interpreted as sub aerial exposure of the shelf, is also clearly recognized on the profiles of this study. Four to five seismic units are truncated by this unconformity (Figure 5). These units can be correlated with the geological formations exposed on land. Unit 5 (Figures 5 \& 7) is comparable with the Upper Cretaceous-Eocene volcanics exposed onland of both sides of the northern part of the Istanbul Strait [43]. Units 4, 3 and 2 can be correlated with OligoceneMiocene aged formations on land. Paleochannels incising Unit 3 indicate that the area was subjected to erosion at that time. The presence of a huge Messinian Canyon in the southwest shelf area also supports this correlation [72]. Unit 2 observed only at the shelf edge might represent the deposition of sediments at the sea during this erosional period.

As described here and in accordance with Aksu et al. [23], Unit 1 is separated from Unit 2 by the $\alpha$ surface and is composed of the two subunits, $1 \mathrm{~b}$ and $1 \mathrm{a}$ separated by the second discontinuity surface, $\alpha 1$. However, in this study, our observation from the inner part of the shelf and at the strait outlet is slightly different than observations of Hiscott et al. [27] \& Flood et al. [5] and complementary in some way:

a) Unit $1 \mathrm{~b}$ between the two erosional surfaces $\alpha$, and $\alpha 1$ becomes thin and disappears towards the inner shelf (Figures 5 \& 7),

b) $\quad \alpha 1$ intersects $\alpha$ surface beneath levees in the proximal part of the shallow fan system (Figures $7 \& 9$ ), and

c) The extension of Unit $1 \mathrm{~b}$ represents a wedge deposit at the shelf edge and is interpreted as a lowstand wedge (Figure 5).

Unit $1 \mathrm{~b}$ is the extension of parallel beddings above $\alpha$ surface in Hiscott et al. [27] and Flood et al. [5]. If subaqueous conditions were prevailing in the shelf area before $9000 \mathrm{y} \mathrm{BP}$, Unit $1 \mathrm{~b}$ should have been also observed in the inner shelf as well. However, this study demonstrates that Unit $1 \mathrm{~b}$ is absent in the inner shelf. In this case, $\alpha 1$ surface can be interpreted either as a non-depositional discontinuity or as an erosional surface. Non depositional surfaces record episodes of reduced sedimentation, synchronous with a decrease in sand supply and/or storm wave energy [73] and can be formed;

a) With no relative change in water depth and can be accounted for by either controls on decreasing sediment supply or storm-wave regime; b) With a minor increase in water depth during which the sand supply and storm-wave energy regime remained uniform,

c) With a minor landward shift in facies driven by a sealevel rise $[74,75]$. The presence and morphology (shape) of the shallow fan demonstrates that there was an important sediment supply, and hence $\alpha 1$ surface must have been formed during a minor transgression (case 3). On the other hand, considering $\alpha 1$ as an erosional surface, absence of Unit $1 \mathrm{~b}$ may be related to the strength of erosion which was much more effective at the outlet and inner shelf, but leaving the parallel strata in the distal parts. This change could be caused by the changing density contrast between the Black Sea and Mediterranean waters as suggested by Flood et al. [5] under subaqueous conditions. At the beginning of the inflow, the density difference is greater relative to today and hence increases the inflow velocity, creating a strong erosion, but reduces velocities as the differences becomes less. In other words, the flow sourced from the Bosphorus was initially strong and gradually reduced its strength.

There is an alternative evolution mechanism that should be considered to explain the changing erosion strength by time; changing base level or sea level [15]. This can be traced from merging of $\alpha$ and $\alpha 1$ surfaces at shallower depth than $-70 \mathrm{~m}$, which signifies the subaerial part of the shelf area at the beginning of this erosion. Mediterranean waters entering into the Black Sea shelf along the Bosphorus channel were able to erode sediments along its route in the inner and mid-shelf and down to the substratum locally. Such strong erosion is evident from the floor of the channel at the outlet which is devoid of sediment infill (Figure 9) and/or overlaid by coarse grained (sand-rich) sediments. The erosion down to basement rock was also shown by Gökaşan et al. [10] from a seismic profile located very close to the strait outlet (in their Figure 11d), although without direct dating. The levees along the channel belonging to Unit $1 \mathrm{~b}$ were deposited later above $\alpha$ surface in the proximal part and blocked the abandoned N-NE trending branch. At a sea level of -70m [27], most of the levees of this shallow fan in the inner shelf would have been located above sea level (Figure 11), hence could have been deposited during a flood from the Bosphorus. The flooding saline Mediterranean waters penetration had an effect on sediment transport on the shoreface, generating density-driven shoreward currents. These currents may cause a significant amount of sediment transport beyond the surf zone in water depths at least up to $-20 \mathrm{~m}$, allowing dispersion of sediment to offshore. Their mostly chaotic internal structure (Figures 5, 7 \& 10) might be related to their formation at subaerial conditions under high density driven shoreward currents. Partly inclined structures at their tops must have been formed after their immediate submergence. This is an alternative explanation for the initially strong but gradually reducing strength of flow by submergence of the shelf area. 
Lowstand wedge deposits of Unit $1 \mathrm{~b}$ must have been deposited during the pre-Holocene lowstand and the subsequent initial rise of sea level as observed elsewhere on the shelf edges of the Black Sea [30,31,34], however dating could not be achieved from this deposit. From a long piston core collected from SW shelf edge of the Black Sea, radiocarbon date of sediments deposited after a marine transgression above a lowstand sediment wedge yielded 8.1 14C ky BP [75]. According to previous studies on the Black Sea shelf, transgression started after around $\sim 8.514 \mathrm{C}$ ky BP [30-32,34,36,38,39,71]. The timing of the first entrance of the Mediterranean waters ranges from 8.4 to $8.214 \mathrm{C}$ ky BP $[34,71,72,76]$. The formation of channel and levee system were dated $\sim 8-7.514 \mathrm{C}$ ky BP in Flood et al. [5] at $-91 \mathrm{~m}$ water depth, implying the sea level of the Black Sea was at the same level with Mediterranean by that time, as the inflow of water was nearly instantaneous lasting no longer than 40 years and possibly as little as a decade according to hydraulic calculations [39]. This must be correct for that part of the fan at the outer shelf, but should be slightly earlier in the inner and mid shelf. The mollusc fauna displays a mixed character of brackish and juvenile euryhaline species and was deposited until $\sim 7.8$ 14C ky BP (considering the core KP12 does not reach the bottom of this sedimentary layer). Brackish mollusc forms characterize the latest lacustrine stage of the Black Sea (Neoeuxinic period), hence mixed fauna represents the influence of Mediterranean waters in this environment. The entrance of the Mediterranean waters must be earlier than 7.8 14C ky BP, due to time necessary for salinity threshold for adaptation of euryhaline species.

Unit $1 \mathrm{~b}$, displaying parallel stratification below $\alpha 1$ (between -92 and $-98 m$ water depths) at the outer shelf [5] might be an evidence of the deposition of the sediments at the submerged part of the shelf that deeper than $-70 \mathrm{~m}$. In the NW shelf, Giosan et al. [24] indicated a sea level of $-40 \mathrm{~m}$ during the Danube was building a delta lobe before the marine reconnection of the Black Sea, by examining a core to $42 \mathrm{~m}$ depth. However, Lericolais et al. [31] pointed out that the bottom of their core corresponds to a proximal part of the forced regression sequence which have started to deposit after $11{ }^{14} \mathrm{C}$ ky BP and argued that the location of this core might have been from the upstream in the delta plain. Even at a sea level of $-40 \mathrm{~m}$, banks at the both sides of the channel would have been subaerially exposed (Figure 11). Following the submergence of the shelf as the sea level rises, continuous Mediterranean undercurrent processes operate on the final form of the fan and sediment distribution. The absence of Unit 1a in the distal part of the channel fan (Chirp Profile 17 on Figure 10) at the outer shelf and exposure of surface $\alpha 1$ indicate continuing Mediterranean undercurrent and non-deposition along its present route. Asymmetrical sediment waves are possibly formed by overspill of this flow. Coarse to fine grained sediment deposition from proximal to distal areas indicate the reducing flow velocities and also splitting into channel network.

The benthic foraminiferal fauna within the sandy sediments consists of various Mediterranean immigrant species transported with sands from the Bosphorus and only some of them could accommodate to this environment after $\sim 6{ }^{14} \mathrm{C}$ ky BP. However increasing population of benthic foraminifers and dominance of euryhaline mollusc fauna occurs after $\sim 6{ }^{14} \mathrm{C}$ ky BP, indicating a continuous flow and also relatively increasing salinity conditions at the bottom water of the shelf area. Decreasing diversity of euryhaline benthic foraminifer fauna from base to upper part of the core indicates that most of the Mediterranean immigrant species could not tolerate to adaptation or not reach to high population. Uncalibrated radiocarbon dates from Dreissena and Mytilus shells are $7.8{ }^{14} \mathrm{C}$ ky BP and $6.2{ }^{14} \mathrm{C}$ ky BP, from intervals $214-211 \mathrm{~cm}$ and $130128 \mathrm{~cm}$, respectively (Calibrated ages in Table 2). Most of the Mediterranean immigrant benthic foraminifer species diminish and/or are not found at $\sim 6 \mathrm{ky}$ BP. Following this change, euryhaline (\%o 1-26) A. tepida and A. parkinsoniana become more abundant first, and polyhaline (\%o18-26; [78]) A. compacta prevails later at $~ 3.9 \mathrm{ky}$ BP (by assuming a constant sedimentation rate and extrapolating from dates in Table 2). These three species are the most common benthic foraminifers occurring in the recent sediments of the Black Sea [77-79]. The colonization order of these species indicates a relative increase in salinity after the transition to marine conditions as inferred from mollusc fauna. However, benthic foraminiferal abundance decreases at the uppermost $50 \mathrm{~cm}$ and is represented by dominantly Ammonia genus.

This changing salinity conditions are in agreement with ecozones based on the calcareous nannoplankton [80] and benthic faunal assemblages [79]. Recently, the sedimentary sequence discovered at archaeological excavations in ancient Byzantium Harbour (Istanbul) at the northern coastal plain of the Marmara Sea indicated that the sea level was much lower than $-6 \mathrm{~m}$, when Neolithic culture settled in the area at $8.4{ }^{14} \mathrm{C}$ ky BP and lived at least a millennia [81], until inundation of this coastal area at about $6{ }^{14} \mathrm{C}$ ky BP. This final maximum rise to present-day sea level occurring simultaneously at the Black Sea might have benefited this fauna.

Longer coring, particularly at the proximal part of the fan and at the lowstand wedge is necessary to resolve and to validate the ages and natures of Unit 1 and $\alpha$ surfaces. Spatial distribution of seismic unit thicknesses by mapping would also help for a conclusive interpretation of the process of reconnection between the Marmara Sea and the Black Sea [82].

Additional output of this study is the recognition of the banks and linear bedforms at the eastern and western shelf area of the shallow fan system (Figure 11). Banks along at both side of the channel at 20 to $45 \mathrm{~m}$ water depth and linear ridge-shaped features are found to be closely related with the substratum formations rising to the sea floor (Figure 11). It can be suggested that the occurrence of these formations at the eastern side of the channel might have caused the channel to redirect sharply its route from NE to NW. This should also be considered as a research topic for future investigations. 


\section{Conclusion}

A shallow fan system, which consists of a channel and its short distributary branches, levees and sediment waves, is defined at the confluence of the Bosphorus and the Black Sea shelf, based on high resolution bathymetrical and seismic data. The volume of the materials constituting the fan is comparable in magnitude to the volume of the Bosporus Strait empty of sediments if we consider the material of the fan was excavated from the floor of the Strait. This fan is built by an aggrading and avulsing channel which flows from the outlet of the Bosphorus into the shelf area. It has developed above the major erosional surface $\alpha$ and less marked one, $\alpha 1$. Unit $1 \mathrm{~b}$ is a seismic unit between two erosional surfaces, representing a lowstand wedge at the shelf edge, whereas it is absent after thinning in the inner shelf. Depositional features belonging to this fan system are defined as Unit 1a. The levees are characterized by mostly chaotic seismic reflectors and are thicker deposits accumulated in proximal areas along the main channel. As the channel becomes shallower and branches towards north, these depositional features appear to be cut by the active channel and its short branches (distributaries). The main channel is a very young formation as the recent sediments have not filled it, and it has erosive evidences of Mediterranean undercurrent due to present oceanography. The banks at both sides of the strait outlet and linear bedforms in the western and eastern shelf area of the channel are associated with the outcropping formation from the substratum.

The evolution mechanism for this fan system is shown to have initiated after a relatively strong Mediterranean-originated northerly flow into the partly subaerially exposed shelf area in the Black Sea. Mollusc and benthic foraminiferal assemblages indicated a transition from fresh/brackish to marine conditions earlier than $7.8{ }^{14} \mathrm{C}$ ky BP (8 300 - $8000 \mathrm{cal}$. a. BP) and continuous marine conditions since $\sim 6{ }^{14} \mathrm{C}$ ky BP $(\sim 7000 \mathrm{Cal}$ a. BP $)$.

\section{Acknowledgements}

This work was supported by TÜBİTAK (The Scientific and Technological Research Council of Turkey), under the Programme of PIA-BOSPHORUS with project number PIA105Y156. Seismic Laboratory (SeisLab) of Institute of Marine Science and Technology (Dokuz Eylül University) were activated by a grant (Project Code: 2003K120369) from State Planning Organization of Turkey (DPT). We wish to acknowledge our thanks to the Captains and crew of R/V K. Piri Reis, R/V Arar and R/V Le Suroit, for their help during data acquisition. We extend our thanks to Prof. A. Aksu, for his kind collection of gravity cores for us, during his research cruise.

\section{References}

1. Latif MA, Özsoy E, Oguz T, Ünlüata Ü (1991) Observations of the Mediterranean inflow into the Black Sea. Deep Sea Research Part A. Oceanographic Research Papers 38(Supplement 2): S711-S723.

2. Di Iorio D, Yüce H (1999) Observations of Mediterranean flow into the Black Sea. Journal of Geophysical Research 104(C2): 3091-3108.
3. Ozsoy E, Di Iorio D, Gregg MC, Backhaus JO (2001) Mixing in the Bosphorus Strait and the Black Sea continental shelf: observations and a model of the dense water outflow. Journal of Marine Systems 31(13): 99-135.

4. Lericolais G, Le Drezen E, Nouzé H, Gillet H, Ergun M, et al. (2002) Recent canyon heads evidenced at the Bosphorus outlet. EOS transactions. AGU Fall Meet Suppl 83(47): Abstract PP71B-0409.

5. Flood RD, Hiscott RN, Aksu AE (2009) Morphology and evolution of an anastomosed channel network where saline underflow enters the Black Sea. Sedimentology 56(3): 807-839.

6. Hiscott RN, Aksu AE, Flood RD, Kostylev V, Yaşar D (2013) Widespread overspill from a saline density-current channel and its interaction with topography on the south-west Black Sea shelf. Sedimentology 60(7): 1639-1667.

7. Okay S, Jupinet B, Lericolais G, Cifci G, Morigi C (2011) Morphological and Stratigraphic Investigation of a Holocene Subaqueous Shelf Fan, North of the Istanbul Strait in the Black Sea. Turkish Journal of Earth Sciences 20(3): 287-305.

8. Ryan WBF, Vachtman D, McHugh C, Çağatay MN, Mart Y (2014) A Channeled Shelf Fan Initiated by Flooding of the Black Sea. In: Goffredo S, Dubinsky Z (Eds.), The Mediterranean Sea: Its history and present challenges. Springer Science+ Business Media, Dordrecht, USA, pp. 1128.

9. Okay S, Lericolais G, Cifci G (2007) Geophysical Investigations at Bosphorus Outlet in Black Sea, European Geosciences Union. Geophysical Research Abstracts. European Geosciences Union, Vienna (Ost.) 9: 00852.

10. Gökaşan E, Tur H, Ecevitoglu B, Gorum T, Turker A, et al. (2005) Evidence and implications of massive erosion along the Strait of Istanbul (Bosphorus). Geo-Marine-Letters 25(5): 324-342.

11. Gökaşan E, Demirbag E, Oktay FY, Ecevitoglu B, Simsek M, et al. (1997) On the origin of the Bosphorus. Marine Geology 140(1-2): 183-199.

12. Stanev EV, Simeonov JA, Peneva EL (2001) Ventilation of Black Sea pycnocline by the Mediterranean plume. Journal of Marine Systems 31(1-3): 77-97.

13. Tolmazin D (1985) Changing Coastal oceanography of the Black Sea. I: Northwestern Shelf. Progress in Oceanography 15(4): 217-276.

14. Yuce $H$ (1996) On the variability of Mediterranean water flow into the Black Sea. Continental Shelf Research 16(11): 1399-1413.

15. Harff J, Flemming NC, Groh A, Hunicke B, Lericolais G, et al. (2017) Sea Level and Climate. Chap.2. In: Flemming NC, Harff J, Moura D, Burgess A, Bailey GN (Eds.), Submerged Landscapes of the European Continental Shelf: Quaternary Paleoenvironments. Wiley, pp. 11-49.

16. Lericolais G (2017) Late Pleistocene Environmental Factors defining the Black Sea, and Submerged Landscapes on the Western Continental Shelf. Chap.17. In: In: Flemming NC, Harff J, Moura D, Burgess A, Bailey GN (Eds.), Submerged Landscapes of the European Continental Shelf: Quaternary Paleoenvironments. Wiley, pp. 479-495.

17. Arkhipov SA, Ehlers J, Johnson RG, Wright HEJ (1995) Glacial drainage towards the Mediterranean during the middle and late Pleistocene. Boreas 24(3): 196-206.

18. Deuser WG (1972) Late-Pleistocene and Holocene history of the Black Sea as indicated by stable isotope studies. Jour Geophys Res 77(6): 1071-1077.

19. Kerey IE, Meric E, Tunoglu C, Kelling G, Brenner RL, et al. (2004) Black Sea-Marmara Sea Quaternary connections: new data from the Bosphorus, Istanbul, Turkey. Palaeogeography, Palaeoclimatology, Palaeoecology 204(3-4): 277-295. 
20. Ostrovskiy AB, Izmaylov YA, Balabanov IP, Skiba SI, Skryabina NG, et al. (1977) New data on the paleohydrological regime of the Black Sea in the Upper Pleistocene and Holocene. In: Kaplin PA, Shcherbakov FA (Eds.), Paleogeography and Deposits of the Pleistocene of the Southern Seas of the USSR. Nauka Press, Moscow, pp. 131-141.

21. Panin N, Popescu I (2007) The northwestern Black Bea: climatic and sea level changes in the Upper Quaternary. In: Yanko-Hombach V, Gilbert AS, Panin N, Dolukhanov PM (Eds.), The Black Sea Flood Question: Changes in Coastline, Climate, and Human Settlement, NewYork, USA, pp. 387-404.

22. Stanley DJ, Blanpied C (1980) Late Quaternary water exchange between the eastern Mediterranean and the Black Sea. Nature 285(5766): 537541.

23. Aksu AE, Hiscott RN, Yasar D, Isler FI, Marsh S (2002) Seismic stratigraphy of Late Quaternary deposits from the southwestern Black Sea shelf: evidence for non-catastrophic variations in sea-level during the last 10000 yr. Marine Geology 190(1-2): 61-94.

24. Giosan L, Filip F, Constatinescu S (2009) Was the Black Sea catastrophically flooded in the early Holocene? Quaternary Science Reviews 28(1-2): 1-6.

25. Görür N, Cagatay MN, Emre O, Alpar B, Sakinç M, et al. (2001) Is the abrupt drowning of the Black Sea shelf at $7150 \mathrm{yr}$ BP; a myth? Marine Geology 176(1-4): 65-73.

26. Hiscott RN, Aksu AE (2002) Late Quaternary history of the Marmara Sea and Black Sea from high-resolution seismic and gravity-core studies. Marine Geology 190(1-2): 261-282.

27. Hiscott RN, Asku AE, Mudie PJ, Marret F, Abrajano T, et al. (2007) A gradual drowning of the southwestern Black Sea shelf: Evidence for a progressive rather than abrupt Holocene reconnection with the eastern Mediterranean Sea through the Marmara Sea Gateway. Quaternary International 167-168: 19-34.

28. Lericolais G, Popescu I, Guichard F, Popescu SM (2007a) A Black Sea lowstand at $8500 \mathrm{yr}$ B.P. indicated by a relict coastal dune system at a depth of $90 \mathrm{~m}$ below sea level. In: Harff J, Hay WW, Tetzlaff DM (Eds.) Coastline Changes: Interrelation of Climate and Geological Processes. GSA Books; Allen Press, Inc., Special Paper 426, pp. 171-188.

29. Lericolais G, Popescu I, Guichard F, Popescu SM, Manolakakis L (2007b) Water-level fluctuations in the Black Sea since the Last Glacial Maximum. In: Yanko-Hombach V, Gilbert AS, Panin N, Dolukhanov PM (Eds.), The Black Sea Flood Question: Changes in Coastline, Climate, and Human Settlement. Springer, USA, pp. 437-452.

30. Lericolais G, Bulois C, Gillet H, Guichard F (2009) High frequency sea level fluctuations recorded in the Black Sea since the LGM. Global and Planetary Change 66(1-2): 65-75.

31. Lericolais G, Guichard F, Morigi C, Minereau A, Popescu I, et al. (2010) A post Younger Dryas Black Sea regression identified from sequence stratigraphy correlated to core analysis and dating. Quaternary International 225(2): 199-209.

32. Lericolais G, Guichard F, Morigi C, Popescu I, Bulois C, et al. (2011) Assessment of Black Sea water-level fluctuations since the Last Glacial Maximum. In: Buynevich I, Yanko-Hombach V, Gilbert AS, Martin RE (Eds.), Geology and Geoarchaeology of the Black Sea Region: Beyond the Flood Hypothesis. The Geological Society of America, Boulder, Colorado, USA, pp. 33-50

33. Ryan WBF, Pitman WC, Major CO, Shimkus KM, Moskalenko V, et al (1997) An abrupt drowning of the Black Sea shelf. Marine Geology 138(1-2): 119-126.

34. Ryan WBF, Major CO, Lericolais G, Goldstein SL (2003) Catastrophic Flooding of the Black Sea. Annu Rev Earth Planet Sci 31(1): 525-554.
35. Mudie PJ, Yanko-Hombach V, Kadurin SV (2014) The Black Sea Dating Game and Holocene Marine Transgression. Open Journal of Marine Science 4(1): 1-7.

36. Nicholas WA, Chivas AR, Murray Wallace CV, Fink D (2011) Prompt transgression and gradual salinisation of the Black Sea during the early Holocene constrained by amino acid racemization and radiocarbon dating. Quaternary Science Reviews 30(27-28): 3769-3790.

37. Soulet G, Ménot G, Lericolais G, Bard E (2011) A revised calendar age for the last reconnection of the Black Sea to the global ocean. Quaternary Science Reviews 30(9-10): 1019-1026.

38. Constantinescu AM, Toucanne S, Dennielou B, Jorry SJ, Mulder T, et al (2015) Evolution of the Danube Deep-Sea Fan since the Last Glacial Maximum: new insights into Black Sea water-level fluctuations. Marine Geology 367: 50-68.

39. Yanchilina AG, Ryan WBF, McManus JF, Dimitrov P, Dimitrov D, et al. (2017) Compilation of geophysical, geochronological, and geochemical evidence indicates a rapid Mediterranean-derived submergence of the Black Sea's shelf and subsequent substantial salinification in the early Holocene. Marine Geology 383: 14-34.

40. Algan O, Ergin M, Keskin E, Gökasan E, Alpar B, et al. (2007) Sea-level changes during the Late Pleistocene-Holocene on the southern shelves of the Black Sea. In: Yanko-Hombach V, Gilbert AS, Panin N, Dolukhanov PM (Editors), The Black Sea Flood Question: Changes in Coastline, Climate, and Human Settlement. Springer, New-York, USA, pp. 603-631.

41. Nearing MA, Norton LD, Bulgakov DA, Larionov GA, West LT, et al. (1997) Hydraulics and erosion in eroding rills Water Resources Research 33(4): 865-876.

42. Yilmaz Y, Gokasan E, Erbay AY (2010) Morphotectonic development of the Marmara Region. Tectonophysics 488(1-4): 51-70.

43. Oktay FY, Gokasan E, Sakinc M, Yaltirak C, Imren C, et al. (2002) The effects of the North Anatolian Fault Zone on the latest connection between Black Sea and Sea of Marmara. Marine Geology 190(1-2): 367-382.

44. Algan O, Çagatay N, Chepalyga AL, Ongan D, Eastoe C, et al. (2001) Stratigraphy of the sediment infill in Bosphorus Strait: water exchange between the Black and Mediterranean Seas during the last glacialHolocene. Geo-Marine Letters 20(4): 209-218.

45. Çagatay MN, Gorur N, Algan O, Eastoe C, Chepalyga AL, et al. (2000) Late Glacial-Holocene palaeoceanography of the Sea of Marmara: timing of connections with the Mediterranean and the Black Seas. Marine Geology 167(3-4): 191-206.

46. Stanev EV (2005) Understanding Black Sea dynamics; An Overview of Recent Numerical Modeling. Oceanography 18(2): 56-75.

47. Oguz T, Dippner JW, Kaymaz Z (2006) Climatic Regulation of the Black Sea hydro-meteorological and ecological properties at interannual-todecadal time scales. J Marine Systems 60(3-4): 235-254.

48. Korotaev GK, Saenko OA, Koblinsky CJ (2001) Satellite altimetry observations of the Black Sea level. Journal of Geophysical Research: Oceans 106(C1): 917-933.

49. Oguz T, Latun VS, Latif MA, Vladimirov VV, Sur HI, et al. (1993) Circulation in the surface and intermediate layers of the Black Sea. Deep Sea Research Part I: Oceanographic Research Papers 40(8): 1597-1612.

50. Oguz T, Malanotte Rizzoli P, Ducklow HW, Murray JW (2002) Interdisciplinary Studies Integrating the Black Sea Biogeochemistry and Circulation Dynamics. Oceanography 15(3): 4-11.

51. Stanev EV, Palazov A, He Y, Peneva E, Grayek S, et al. (2016) First diagnosis from Argo data in the Black Sea. Euro-Argo RI European contribution to Argo program. http://www.euroargo.eu/ 
MainAchievements/EuropeanContributions/ScientificResults/BlackSea.

52. Korotaev GK, Oguz T, Riser S (2006) Intermediate and deep currents of the Black Sea obtained from autonomous profiling floats. Deep Sea Research Part II: Topical Studies in Oceanography 53(17-19): 19011910.

53. Murray JW, Stewart K, Kassakiank S, Krynytzky M, DiJulio D (2007) Oxic, Suboxic and Anoxic Conditions in the Black Sea. In: YankoHombach V, Gilbert AS, Panin N, Dolukhanov PM (Eds.), The Black Sea Flood Question: Changes in Coastline, Climate, and Human Settlement, pp. 437-452.

54. Algan O, Gokasan E, Gazioglu C, Yucel ZY, Alpar B, et al. (2002) A highresolution seismic study in Sakarya Delta and Submarine Canyon, southern Black Sea shelf. Continental Shelf Research 22(10): 15111527.

55. Demirbag E, Gökasan E, Oktay FY, Simsek M, Yüce H (1999) The last sea level changes in the Black Sea: evidence from the seismic data. Marine Geology 157(3-4): 249-265.

56. Okyar M, Ediger V, Ergin M (1994) Seismic stratigraphy of the southeastern Black Sea shelf from high-resolution seismic records. Marine Geology 121(3-4): 213-230.

57. Lericolais G (2002) BLASON 2 report.

58. Reimer PJ, Bard E, Bayliss A, Beck JW, Blackwell PG, et al. (2013) Intcal13 and Marine13 Radiocarbon Age Calibration Curves 0-50,000 Years Cal Bp. Radiocarbon 55(4): 1869-1887.

59. Stuiver M, Reimer PJ (1993) Extended C-14 Data-Base and Revised Calib 3.0 C-14 Age Calibration Program. Radiocarbon 35(1): 215-230.

60. Siani G, Paterne M, Arnold M, Bard E, Métivier B, et al. (2000) Radiocarbon Reservoir Ages in the Mediterranean Sea and Black Sea. Radiocarbon 42(2): 271-280.

61. Kirci-Elmas E, Algan O, Lericolais G (2009) Benthic Foraminiferal Distribution in Core Sediments from the İstanbul Strait - Black Sea Shelf Exit. In: Odasi TJM (Ed.), 62 ${ }^{\text {nd }}$ Geological Congress of Turkey. MTA-Ankara, Ankara (TK).

62. Yuce H (1996) On the variability of Mediterranean water flow into the Black Sea. Continental Shelf Research 16(11): 1399-1413.

63. Holmes A (1965) Principles of physical geology. Wiley, p. 730.

64. Nemec W, Steel RJ (1988) What is a fan delta and how do we recognize it. Fan Deltas: sedimentology and tectonic settings, pp. 3-13.

65. Prior DB, Bornhold B (1985) Sediment transport on subaqueous fan delta slopes, Britannia Beach, British Columbia. Geo-Marine Letters 5(4): 217-224.

66. Wescott WA, Ethridge FG (1980) Fan-Delta Sedimentology and Tectonic Setting--Yallahs Fan Delta, Southeast Jamaica. AAPG Bulletin 64(3): 374-399.

67. Sacchi M, Molisso F, Violante C, Esposito E, Insinga D, et al. (2009) Insights into flood-dominated fan-deltas: very high-resolution seismic examples off the Amalfi cliffed coasts, eastern Tyrrhenian Sea. Geological Society 322: 33-71.

68. Violante C, Sacchi M, Esposito E, Gargano G, Porfido S, et al. (2005) Flood-dominated Fan Delta System Induced by the A.D. 79 SommaVesuvius Eruption at Amalfi Coast, Southern Italy. In: Michetti FA,
Haldorsen S, Leroy S (Eds.), Final Meeting, Dark Nature - Rapid Natural Change and Human Responses. Atlas Conferences Inc., Villa Olmo, Como, Italy, pp. 20-53.

69. Gupta S, Collier JS, Palmer Felgate A, Potter G (2007) Catastrophic flooding origin of shelf valley systems in the English Channel. Nature 448(7151): 342-345.

70. Gurnell AM, Petts GE (2002) Island-dominated landscapes of large floodplain rivers, a European perspective. Freshwater Biology 47(4): 581-600.

71. Major CO, Goldstein SL, Ryan WBF, Lericolais G, Piotrowski AM, et al. (2006) The co-evolution of Black Sea level and composition through the last deglaciation and its paleoclimatic significance. Quaternary Science Reviews 25(17-18): 2031-2047.

72. Gillet H, Lericolais G, Réhault JP (2007) Messinian event in the Black Sea: evidence of the erosional surface. Marine Geol., 244(1-4): 142165 .

73. Hampson GJ (2000) Discontinuity Surfaces, Clinoforms, and Facies Architecture in a Wave-Dominated, Shoreface-Shelf Parasequence. Journal of Sedimentary Research 70(2): 325-340.

74. Hampson GJ, Storms JEA (2003) Geomorphological and sequence stratigraphic variability in wave-dominated, shoreface-shelf parasequences. Sedimentology 50(4): 667-701.

75. Algan O, Lericolais G, Dondurur D, Okay S, Kirci Elmas E, et al. (2009a) The extension of the Bosphorus Channel (Istanbul strait) at the Black Sea Shelf. In: IGC Programs, IGCP 521- Fifth Plenary Meeting and Field Trip, Istanbul-İzmir-Çanakkale (TK).

76. Ivanova EV, Murdmaa IO, Chepalyga AL, Cronin TM, Pasechnik IV, et al. (2007) Holocene sea-level oscillations and environmental changes on the Eastern Black Sea shelf. Palaeogeography, Palaeoclimatology, Palaeoecology 246(2-4): 228-259.

77. Yanko V (1990) Stratigraphy and Paleogeography of Marine Pleistocene and Holocene Deposits of the Southern Seas of the USSR. Mem Soc Geol Ital 44: 167-187.

78. Meriç E, Görmüs M, Avsar N (2004) Holocene geologic history of the Golden Horn (Istanbul, NW Turkey). In: Yanko-Hombach V, et al., 4th International Congress "Environmental Micropaleontology, Microbiology and Meiobenthology". ISEMMM, Isparta (Turkey), pp. 130-132.

79. Ongan D, Algan O, Kaplan Yesilyurt S, Nazik A, Ergin M, et al. (2009) Benthic Faunal Assemblages of the Holocene Sediments from the Southwest Black Sea Shelf. Turkish Journal of Earth Sciences 18(2): 239-297.

80. Giunta S, Morigi C, Negri A, Guichard F, Lericolais G (2007) Holocene biostratigraphy and paleoenvironmental changes in the Black Sea based on calcareous nannoplankton. Marine Micropaleontology 63(12): 91-110.

81. Algan O, Yalçın MN, Özdoğan M, Yılmaz İ, Sarı E, et al. (2009b) A Short note on the geo-archaeological significance of the ancient Theodosius Harbour (İstanbul-Turkey). Quaternary Research 72(3): 457-461.

82. Snyder WH, Britter RE, Hunt JCR (1980) A fluid modeling study of the flow structure and plume impingement on a three-dimensional hill in stably stratified flow. In: Wind Engineering JW (Ed.), - Cermak, 5th Internat. Conf. Wind Engineering, Fort Collins (USA). Pergamon, New York, USA, 1: 319-329. 
CC (P) This work is licensed under Creative
Your next submission with Juniper Publishers will reach you the below assets

- Quality Editorial service

- Swift Peer Review

- Reprints availability

- E-prints Service

- Manuscript Podcast for convenient understanding

- Global attainment for your research

- Manuscript accessibility in different formats ( Pdf, E-pub, Full Text, Audio)

- Unceasing customer service

Track the below URL for one-step submission https://juniperpublishers.com/online-submission.php 